\title{
R\&D REPORTING BIASES AND THEIR CONSEQUENCES
}

By

\author{
Baruch Lev \\ New York University \\ Bharat Sarath \\ Baruch College \\ Theodore Sougiannis* \\ University of Illinois
}

June 2004

* Corresponding author

The comments of CAR 2000 conference participants and especially of Louis Chan and Josef Lakonishok are much appreciated. 


\title{
R\&D REPORTING BIASES AND THEIR CONSEQUENCES
}

\begin{abstract}
The immediate expensing of $R \& D$ expenditures is often justified by the conservatism principle. However, no accounting procedure consistently applied can be conservative throughout the firm's life. We ask the following questions: (a) When is the expensing of $\mathrm{R} \& \mathrm{D}$ conservative and when is it aggressive, relative to $\mathrm{R} \& \mathrm{D}$ capitalization? and (b) What are the capital market implications of these reporting biases? To address these questions we construct a model of profitability biases (differences between reported profitability under R\&D expensing and capitalization) and show that the key drivers of the reporting biases are the differences between $R \& D$ growth and earnings growth (momentum), and between R\&D growth and return on equity (ROE). Companies with a high $R \& D$ growth rate relative to their profitability (typically early cycle companies) report conservatively, while firms with a low $R \& D$ growth rate (mature companies) tend to report aggressively under current GAAP. Our empirical analysis, covering the period 1972-2003, generally supports the analytical predictions.

In the valuation analysis we find evidence consistent with investor fixation on the reported profitability measures: we detect undervaluation of conservatively reporting firms and overvaluation of aggressively reporting firms. These misvaluations appear to be corrected when the reporting biases reverse from conservative to aggressive and vice versa.
\end{abstract}




\section{R\&D Reporting Biases and Their Consequences}

\section{Introduction}

The immediate expensing of practically all internally-generated intangible investments in the U.S., a questionable procedure given the substantial future benefits of many such investments, is often justified by the conservatism principle. ${ }^{1}$ Conservative accounting procedures, goes the argument, counter managers' prevalent optimism, ${ }^{2}$ and are appropriate given the generally high level of uncertainty associated with the outcome of intangible investments. ${ }^{3}$ However, no accounting procedure consistently applied can be conservative (or aggressive) forever. Over the lifetime of the enterprise, if reported earnings under a conservative accounting rule are understated (relative to a less conservative rule) during certain periods, they have to be overstated in other periods, given that conservative/aggressive accounting procedures essentially shift earnings from one period to another. What then are the conditions under which the expensing of $R \& D$ (and other intangibles) will be conservative, or aggressive, relative to the capitalization of R\&D? And what are the capital market consequences, namely investors' misvalutions of securities, of such conservative (understated earnings) or aggressive (overstated earnings) financial reporting?

We address these two questions in the current study. We focus on three widely-used indicators of performance - the return on equity (ROE), return on assets (ROA), and earnings growth (momentum) - and derive the general conditions under which R\&D expensing (the

\footnotetext{
${ }^{1}$ The only exception in the U.S. to intangibles' expensing is the capitalization of some software development costs, required by SFAS 86. For an empirical examination of software capitalizations, see Aboody and Lev (1998). For a discussion of the evidence concerning R\&D benefits, see Lev (1999).

2 "Thus if the animal spirits are dimmed and the spontaneous optimism falters, leaving us to depend on nothing but a mathematical expectation, enterprise will fade and die." (Keynes, 1936, pp. 161-162).

${ }^{3}$ Kothari et al. (2002) report that the earnings volatility associated with $R \& D$ is three times larger than that associated with tangible investment in property, plant and equipment.
} 
current GAAP procedure) will result in overstated or understated values of these indicators, relative to capitalized $R \& D$. We then examine the validity of these general conservative/aggressive conditions on the sample data ${ }^{4}$. Finally, we address the investor rationality question: Is the conservative/aggressive reporting of enterprise profitability induced by the expensing of $R \& D$, systematically affecting the pricing of securities? That is, do investors properly perceive that over the life-cycle of the firm, a consistent application of R\&D expensing will lead to understatement of profitability in certain periods, and overstatement in other periods? Our empirical analysis, based on a comprehensive sample spanning 32 years (1972-2003), largely validates the general conditions derived analytically for R\&D expensing to generate conservative or aggressive reporting. With respect to investor rationality, we find systematic evidence of mispricing: stocks of conservatively reporting firms are systematically undervalued, while those of aggressively reporting firms are overvalued. Notably, these mispricings tend to be corrected when the reporting biases switch from conservative to aggressive, and vice versa. These effects of an accounting practice (R\&D expensing) on investors' valuations is distinct from previously established effects on valuation, such as those of firm size, book-to-market, and R\&D intensity.

The accounting and finance literature includes extensive research related to our study. We note here our contribution relative to previous studies. Various studies have consistently documented a significant positive relationship between R\&D intensity and subsequent stock returns (the R\&D intensity effect), e.g. Lev and Sougiannis (1996), Chan et al. (2001), Chambers et al. (2002), Penman and Zhang (2002), Eberhard et al (2004). Explanations for the R\&D intensity effect include both mispricing of R\&D expenditures (Chan et al 2001, Eberhard et al

\footnotetext{
${ }^{4}$ By aggressive reporting we do not mean that the companies "manage" or manipulate their reported earnings. Rather, following the full expensing of R\&D mandated by GAAP results in an overstatement of the change in earnings, relative to the capitalization of R\&D.
} 
2004), and risk premium (Chambers et al. 2002) arguments. We demonstrate below that in addition to the R\&D intensity effect, there is a significant reporting profitability bias effect, namely firms that report conservative profitability and earnings growth (relative to same indicators under $\mathrm{R} \& \mathrm{D}$ capitalization) are undervalued, while firms that report aggressive profitability and earnings growth are overvalued. These over/under valuations are distinct from the effects of R\&D intensity on subsequent returns, demonstrated in previous studies. Interestingly, our reporting-related misvaluations are corrected when the reporting biases reverse from conservative to aggressive and vice versa. Our contribution thus lies in identifying a distinct, and particularly relevant to accounting source of capital market misvaluationsreporting biases due to $\mathrm{R} \& \mathrm{D}$ expensing. ${ }^{5}$

Our analytical model contributes to the literature by developing a unified structure of reported profitability biases arising from alternative accounting rules, and documenting empirically the presence of such biases in the sample data. The fact that the immediate expensing of growing expenditures such as $\mathrm{R} \& \mathrm{D}$, results in conservative reporting, whereas the expensing of shrinking expenditures results in aggressive reporting is a standard feature of accounting research and financial statement analysis, e.g. Beaver and Ryan (2000), Monahan (1999), Danielson and Press (2004). However, the rate of growth at which conservative accounting tips over into aggressive reporting depends as our model shows on the particular profitability measure used. We add to prior studies by outlining the cutoff points for conservative/aggressive reporting for three key profitability measures, ROE, ROA and earnings growth, or momentum.

\footnotetext{
${ }^{5}$ Our evidence complements the evidence reported by Luft and Shields (2001) who use an experimental setting in which the subjects are MBA students. Evidence from the experiment indicates that when individuals use information on intangible expenditures to predict profits, expensing the expenditures (versus capitalizing) significantly reduces the accuracy, consistency, consensus, and self-insight of individuals' subjective profit predictions. The authors point out that consistent with psychological theories of learning, individuals do not learn the exact magnitude of the effect of intangibles on future profits as well when the intangibles are expensed. The study implies that decisions based on the expensing of intangibles may lead to mistakes. We confirm with actual data that indeed investors appear to make mistakes, given the expensing of R\&D. In addition, our evidence provides further support to behavioral finance arguments about investor irrationality, e.g. Barberis and Thaler (2003).
} 
We then use the cutoff points to carry out empirical analyses that generate new insights on the R\&D expensing versus capitalizing controversy.

The remainder of the paper proceeds as follows: In Section 2 we construct a model that allows us to identify the drivers of profitability reporting biases, and derive testable hypotheses for the existence and consequences of the biases. In Section 3 we discuss data sources and variable definitions. In Section 4 we validate the model by comparing its predictions to the sample reporting biases. In Section 5 we test the capital market consequences of the biases. Section 6 contains concluding remarks.

\section{Conservative and Aggressive Reporting Under R\&D Expensing}

We derive in this section the general conditions under which the expensing of R\&D will generate conservative (understated) or aggressive (overstated) performance measures, relative to performance measured under the capitalization and amortization of R\&D. We do not prescribe in this study the capitalization or expensing of $R \& D$, or other intangibles. Rather, we postulate that if $R \& D$ expenditures have under certain circumstances future benefits, their immediate expensing will lead to systematic performance reporting biases, relative to underlying earnings under R\&D capitalization. Our interest here is in deriving general rules for identifying such biases.

The analytical results are derived under an assumption of steady R\&D growth, captured through an exogenous parameter, g. Assume that a firm has an initial expenditure $\mathrm{C}$ of $\mathrm{R} \& \mathrm{D}$ in year 1 and that $R \& D$ grows at a rate $g$ per year. Thus, the $R \& D$ expenditure in year $t$ would be $\mathrm{C}(1+\mathrm{g})^{\mathrm{t}}$. The issue we address is the comparison of profitability indicators when the firm expenses $R \& D$ expenditure in year $t$ as opposed to capitalizing and amortizing it over $\mathrm{T}$ years (under the assumption that cash flows are unaffected by the accounting policy and that other 
reporting choices are unchanged). We assume that under the expensing method, the firm has in year $t$ earnings of $E_{t}$ and book value of equity (respectively, assets) of $B E_{t}\left(B A_{t}\right)$. Our analysis relates to years $\mathrm{t}>\mathrm{T}$, that is, after a full $\mathrm{R} \& \mathrm{D}$ amortization cycle is complete. Only in this case can meaningful comparisons be made between expensing and capitalizing policies.

It is important to note, at least from a theoretical perspective, that the results derived in this section can also be obtained in two more complex settings. The first is where R\&D investment determines earnings growth. The second is where there are multiple assets with depreciation calculated on a continuous basis. We do not report those results mainly because they do not lead to any significant changes in our empirical tests. However, it is worth noting that each of these settings generates empirical predictions that may be a potential area of future research. $^{6}$

\section{Notation:}

$\mathrm{E}_{\mathrm{t}} \quad=\quad$ Earnings in year $\mathrm{t}$ under expensing of $R \& D$,

$\mathrm{E}_{\mathrm{t}}^{\mathrm{c}}=$ Earnings in year $\mathrm{t}$ under capitalization and amortization of $R \& D$,

$\mathrm{BVA}_{\mathrm{t}}\left(\mathrm{BVE}_{\mathrm{t}}\right)=$ Book value of assets (equity) at end of year $\mathrm{t}$ under expensing of $R \& D$,

$\mathrm{BVA}_{\mathrm{t}}^{\mathrm{c}}\left(\mathrm{BVE}_{\mathrm{t}}^{\mathrm{c}}\right)=$ Book value of assets (equity) at end of year $\mathrm{t}$ under capitalization and amortization of $R \& D$,

$\mathrm{EM}_{\mathrm{t}}\left(\mathrm{EM}_{\mathrm{t}}^{\mathrm{c}}\right)=$ Earnings growth from year $\mathrm{t}-1$ to $\mathrm{t}$ (momentum) under expensing (capitalization) of $R \& D$.

$\mathrm{T}=\quad$ Amortization period of R\&D investment (for capitalizing firms),

$\mathrm{g}=\quad$ Annual growth rate of $\mathrm{R} \& \mathrm{D}$ expenditures,

$\mathrm{C}=\mathrm{R} \& \mathrm{D}$ expenditure in year 1 ,

$\tau=$ Tax Rate,

\footnotetext{
${ }^{6}$ Results are available from the authors on request.
} 
We focus in the following analysis on three widely used measures of operating performance: return on equity (ROE), return on assets (ROA), and the earnings growth (momentum).

\section{Proposition 1 [ROA, ROE and Non Zero R\&D Growth Rate]}

The R\&D expensing firm reports a higher ROA than the capitalizing firm if and only if: $R O A \geq \frac{(1-\tau) g}{1+\frac{1}{2} g}$. The analogous result for ROE is $R O E \geq g /(1+g / 2)$.

\section{Proof: See Appendix}

\section{Proposition 2 [Earnings Momentum and R\&D Growth Rate]}

The R\&D expensing firm reports a higher earnings growth rate (EM) than the capitalizing firm if and only if $E M_{t} \geq g$. That is, an expensing policy results in a higher reported earnings momentum if and only if the growth of $R \& D$ expenditures is slow relative to the reported (under expensing) earnings growth.

Proof: See Appendix A

A qualification to the preceding propositions concerns the underlying assumption that earnings are positive and higher under capitalization than under expensing (see Appendix A). For instance, Proposition 2 fails if $E_{t}>E_{t}^{c}>0$. Similarly, Proposition 1 depends on a steady growth in R\&D over the entire amortization period and may fail if growth is uneven. ${ }^{7}$

\footnotetext{
${ }^{7}$ A real-life example of such aggressive reporting of ROE is provided by Lev and Sougiannis (1996, Appendix) for Merck \& Co. In 1991 Merck's annual R\&D growth rate was 15.7\%, substantially lower than reported ROE (0.55). Our model (above) suggests that in this case (where ROE $>g /((1+\mathrm{g} / 2))$, the return on equity under capitalization of $\mathrm{R} \& \mathrm{D}$ will be lower than ROE under expensing. This, indeed, is the case for Merck: ROE under capitalization was 0.40 in 1991, compared with a reported ROE of 0.55. Further, Merck's reported 3-year earnings change in 1991 (relative to 1988) was 76\%. This growth rate is higher than the 1991 (3-year) R\&D growth rate $(47.7 \%)$, and our model predicts that in this case the reported momentum will be higher (aggressive reporting) than the earnings momentum under R\&D capitalization. This, indeed, is the case: The 1991 (3-year) momentum under R\&D capitalization is $70 \%$, while the reported momentum is $76 \%$.
} 
Given the expensing rule for R\&D expenditures mandated by SFAS 2, our above propositions lead us directly to the following testable hypotheses:

H1: Let $g$ denote the $R \& D$ growth rate. If $[g /(1+g / 2)]$ is greater (less) than reported ROE then ROE under R\&D capitalization is greater (less) than ROE under expensing of R\&D.

H2: When the R\&D growth rate is greater (less) than earnings growth under $R \& D$ expensing then earnings growth under capitalization is greater (less) than earnings growth under R\&D expensing.

We thus established cut-off rules indicating when reported profitability will be conservative (reported ROE, ROA, and earnings growth lower than under capitalization), and when reported profitability is aggressive (reported indicators higher than under capitalization).

In addition, our propositions imply that under the current expensing rule, understanding the relationship between $R \& D$ investment growth and profitability is important for stock market valuation purposes. In theory, market value should be based on economic profitability, and any distortions of economic profitability measures due to the application of economically inconsistent accounting rules could lead to stock market misvaluations if investors fixate on reported profitability. For example, for firms with $\mathrm{R} \& \mathrm{D}$ growth rate sufficiently large relative to reported profitability, undervaluation is possible because the effects on income outweigh the asset-reduction resulting from leaving the $R \& D$ asset off the balance sheet. However, even if the market fixates on reported profitability, it cannot undervalue assets forever. The reason is that a point in time comes at which the difference between reported and economic profitability (the 
reporting bias) reverses. In our setting, this happens when the R\&D growth rate drops below the cutoff value indicated in Proposition 1. At that point investors should be taking the appropriate action to correct any prior misvaluation. This reasoning leads us to the following testable hypotheses:

H3: Firms with R\&D growth rate $g$, such that $[g /(1+g / 2)]$ is greater (less) than reported ROE, are undervalued (overvalued) and this misvaluation is corrected when the R\&D growth rate drops below the cutoff $2 \mathrm{ROE} /(2-\mathrm{ROE})$.

H4: Stocks with R\&D growth rate greater (less) than reported earnings momentum are undervalued (overvalued), and this misvaluation is corrected when the R\&D growth rate becomes less (greater) than reported earnings momentum.

The importance of systematic misvaluations, if present, is that they may lead to social harm. Systematic undervaluations, for example, imply an excessively high cost of capital, which in turn hinders investment and growth. Conversely, overvaluations lead to undesirable wealth transfers from outside investors to insiders, given the considerable information asymmetries associated with $\mathrm{R} \& \mathrm{D} .^{8}$ The remaining of the paper empirically tests the above four hypotheses.

\section{Data and Measures}

Our sources of data are the Compustat and CRSP databases. We use data for the period 1972 to 2003, and include in our samples all firms with valid data in the Compustat Active and Research files for the following variables: sales (item no. 12), R\&D expenditures (item no. 46), book value of common equity (item no. 60), and net income (item no. 172). Market value of

\footnotetext{
${ }^{8}$ Indeed, Aboody and Lev (2000) report that insider gains in R\&D-intensive companies are substantially higher than in firms with no (or low) R\&D.
} 
common equity (price per share times number of shares outstanding), and stock returns are derived from the CRSP Stock Return files.

For each firm we compute the annual amortization of $R \& D$ (distinct from the $R \& D$ expenditure which is expensed in the financial report) as well as the R\&D capital calculated from the time-series of reported $R \& D$ expenses (Compustat item no. 46). The $R \& D$ amortization and capital values are used to derive earnings and book values under $R \& D$ capitalization by adjusting both the reported earnings (Compustat item no. 172) and book values of equity (Compustat item no. 60). Firm-specific estimates of R\&D amortization are generally too noisy and unreliable, given the relatively short time series of R\&D available and the high serial correlation of annual R\&D expenditures for most firms. Industry-specific amortization rates, such as those estimated by Lev and Sougiannis (1996) are more reliable. For this study, encompassing all Compustat companies with R\&D data, we adopt a uniform R\&D amortization rate of $20 \%$ per year. ${ }^{9}$ Accordingly, the R\&D amortization in year $t\left(\mathrm{RDA}_{t}\right)$ is $20 \%$ of all the previous R\&D expenditures (vintages) which are still productive (i.e., not fully amortized):

$$
\mathrm{RDA}_{i t}=0.2 *\left(\mathrm{RD}_{i t-1}+\mathrm{RD}_{i t-2}+\mathrm{RD}_{i t-3}+\mathrm{RD}_{i t-4}+\mathrm{RD}_{i t-5}\right) .
$$

The $R \& D$ capital at the end of year $t\left(R D C_{t}\right)$ is the sum of the unamortized $R \& D$ expenditures (vintages) which are still productive:

$$
\mathrm{RDC}_{i t}=\mathrm{RD}_{i t}+0.8 \times \mathrm{RD}_{i t-1}+0.6 \times \mathrm{RD}_{i t-2}+0.4 \times \mathrm{RD}_{i t-3}+0.2 \times \mathrm{RD}_{i t-4} .
$$

Table 1 provides summary statistics of our sample. The data indicate that R\&D expenditures have grown sharply over time. As a percentage of sales, R\&D expenditures were $1.70 \%$, on average, in 1975 and more than doubled by 2000 to $4.54 \%$. It is also interesting to note that as a percentage of earnings, R\&D expenditures have grown from $36.1 \%$ in 1975 to $96.9 \%$ in 2000 . Since firms' R\&D expenditures have generally increased over time, the annual

\footnotetext{
${ }^{9}$ Uniform rates are frequently used in economic research (e.g., the 15\% rate assumed in Hall et al., 1988).
} 
R\&D amortization is smaller than the annual accounting expense, as indicated by the lower R\&D intensity ratios based on $R \& D$ capitalization than those based on $R \& D$ expensing. The data in Table 1 also show that R\&D capital represents a relatively large intangible asset, accounting for $25 \%$ of the book value of equity in 2000 , even with our assumed fast amortization rate of R\&D (20\% per year).

Table 2 presents data on the growth rate of $R \& D$, the growth rate (momentum) of earnings, and return on equity -- three key variables in our study. The growth rates of R\&D and earnings are computed over five years: $\left.[\mathrm{R} \& \mathrm{D} \text { (or earnings) }-\mathrm{R} \& \mathrm{D} \text { (or earnings) })_{\mathrm{t}-4}\right] / \mathrm{R} \& \mathrm{D}$ (or earnings) $)_{\mathrm{t}-4}$. When earnings $\mathrm{t}_{\mathrm{t}-4}$ is negative we use their absolute value in the denominator. ${ }^{10}$ Table 2 presents data for the most R\&D-intensive industries and for selected years. For practically all industries (except pharmaceuticals), the 5-year growth rate of R\&D plummeted in 1990, relative to 1985 (e.g., from $124.8 \%$ to $31.4 \%$ in software), perhaps induced by the onset of the recession in the US in the early 1990s and by the maturing of several industries. In a few industries (software, transportation), R\&D growth picked up in the early 1990 s and by 2000 there are signs of higher growth in all industries reported except drugs and pharmaceuticals. ${ }^{11}$

The earnings growth patterns (middle three columns in Table 2) portray a different picture than the R\&D growth. The earnings growth of pharmaceutical companies decreased over the examined period, while their R\&D growth was largely constant, perhaps due to HMO and Medicare/Medicaid pressure on drug prices and usage in the 1990s. In contrast, the earnings growth rate of computers, measuring instruments, transportation equipment and electrical equipment companies soared in the first half of the 1990s, despite flat or decreasing growth rates of R\&D in those industries. However, in the second half of the 1990s the earnings growth rates

\footnotetext{
${ }^{10} \mathrm{We}$ also used a three-year growth rate calculation. The empirical results are almost identical to those reported below.

${ }^{11}$ A recent report by the Council on Competitiveness, written by Porter and Stern (Porter and Stern 1999), strongly warns about dangers to U.S. competitiveness from decreases in the growth rate of R\&D, particularly basic research.
} 
of these industries have declined substantially. In particular, a growth rate of $8.8 \%$ for computers reflects the strong competition in the industry. Communications companies exhibited at the median, a negative earnings growth in the early 1990s, probably as a result of the extensive deregulation in this industry (e.g., the opening up of intrastate phone service to competition), but they seem to be recovering in the late 1990s.

Median return on equity (ROE) values vary across years and industries with the most stable pattern exhibited by transportation. In year 2000, four out of seven industries had negative median ROEs and apparently software and drug companies suffered large losses.

Considering the main variables driving our analysis, almost two thirds of the sample firm-years (62.4\%) had an R\&D growth rate which was higher than the earnings momentum, leading according to our model to conservative reporting of earnings growth and to potential market under-valuation. In the remaining one third $(37.6 \%)$ of the sample cases, the R\&D growth rate was lower than the earnings momentum, leading to an aggressive earnings growth reporting and to potential market over-valuation. In $61 \%$ of the firm-years, R\&D growth was higher than ROE, leading according to our model to conservative ROE reporting with potential market under-valuation, and aggressive reporting in the remaining $39 \%$ of the cases with potential market over-valuation.

\section{Validating the Model's Predictions}

In this section we examine the empirical support for our hypotheses $\mathrm{H} 1$ and $\mathrm{H} 2$ derived from propositions 1 and 2 in Section 2. Using the notation, RDG(5) for the five-year R\&D growth rate, $\mathrm{RDG}$ for the annual $\mathrm{R} \& \mathrm{D}$ growth rate, $\mathrm{ROE}$ for the reported ( $\mathrm{R} \& \mathrm{D}$-expensed) return on equity, $\mathrm{ROE}^{\mathrm{C}}$ for the $\mathrm{R} \& \mathrm{D}$-capitalized $\mathrm{ROE}, \mathrm{EM}(5)$ for the five-year reported earnings 
growth (momentum), and $\mathrm{EM}(5)^{\mathrm{C}}$ for the five-year earnings momentum under R\&D capitization, we restate our two hypotheses as follows:

H1: If $\{\mathrm{RDG} /[(\mathrm{RDG} / 2)+1]\}>\mathrm{ROE}$ then $\mathrm{ROE}<\mathrm{ROE}^{\mathrm{C}}$, and the converse for $\{\mathrm{RDG} /[(\mathrm{RDG} / 2)+1]\}<\mathrm{ROE}$. Namely, if the growth rate of R\&D divided by 1 plus half the R\&D growth rate is larger than the firm's ROE under expensing, then that ROE will be conservative (lower than ROE under R\&D capitalization).

H2: If $\operatorname{RDG}(5)>\operatorname{EM}(5)$ then $\operatorname{EM}(5)<\operatorname{EM}(5)^{\mathrm{C}}$, and the converse for $\mathrm{RDG}(5)<\operatorname{EM}(5)$. Namely, if the five-year growth rate of R\&D is larger than the five-year growth rate of reported earnings under R\&D expensing, then reported earnings growth is conservative (lower than reported earnings growth under R\&D capitalization).

Since these relationships are not linear, we use a portfolio approach to examine their validity and then also employ a regression approach. We implement two alternative variations of the portfolio approach. In the first, sample companies with valid data were ranked in each year into nine portfolios, in decreasing sizes of $\operatorname{RDG}(5)$ and $\operatorname{EM}(5)$ (and alternatively in decreasing sizes of $\{\mathrm{RDG} /[(\mathrm{RDG} / 2)+1]\}$ and $\mathrm{ROE})$. Thus, sample firms were first classified in each year into three portfolios based on decreasing size of earnings momentum, $\operatorname{EM}(5)$, and then within each of the three $\operatorname{EM}(5)$ portfolios firms were classified into three decreasing R\&D growth, RDG(5), portfolios. The same procedure was applied to the R\&D growth and return on equity indicators, yielding nine size-ranked $\{\mathrm{RDG} /[(\mathrm{RDG} / 2)+1]\}$ and $\mathrm{ROE}$ portfolios. In each of the nine $\mathrm{RDG}(5)-\mathrm{EM}(5)$ portfolios, and the nine $\{\mathrm{RDG} /[(\mathrm{RDG} / 2)+1]\}-\mathrm{ROE}$ portfolios we focus on the reporting biases, in earnings growth (momentum) and ROE, namely the differences between reported (R\&D expensed) and R\&D-capitalized earnings momentum, $\operatorname{EM}(5)-\operatorname{EM}(5)^{\mathrm{C}}$, and between reported and R\&D-capitalized ROE, ROE - ROE ${ }^{\mathrm{C}}$. 
In the second variation of the portfolio tests we control for R\&D intensity, measured by the $R \& D$ expenditures to sales ratio. ${ }^{12}$ This is a more demanding test than the above because it controls not only for R\&D growth but also for R\&D intensity (level of the expenditure), which is likely to affect the size of the reporting bias in ROE and earnings momentum. In this test, sample companies with valid data were ranked in each year into nine portfolios, in decreasing sizes of RDG(5)-EM(5) and R\&D-to-sales (and alternatively in decreasing sizes of $\{\mathrm{RDG} /[(\mathrm{RDG} / 2)+1]\}-\mathrm{ROE}$ and R\&D-to-sales). Thus, sample firms were first classified in each year into three portfolios based on decreasing size of $\operatorname{RDG}(5)-\operatorname{EM}(5)$, and then within each of the three RDG(5)-EM(5) portfolios firms were classified into three decreasing R\&D-to-sales (RDS) portfolios. The same procedure was applied to the R\&D growth and return on equity relationship, yielding nine size-ranked $\{\mathrm{RDG} /[(\mathrm{RDG} / 2)+1]\}-\mathrm{ROE}$ and $\mathrm{R} \& \mathrm{D}-$-to-sales portfolios.

Table 3 presents data for the relationship between annualized R\&D growth, $\{\mathrm{RDG} /[(\mathrm{RDG} / 2)+1]\}$, and return on equity, ROE, based on the second test (including R\&D intensity). ${ }^{13}$ We expect $(\mathrm{H} 1)$ that when $\{\mathrm{RDG} /[(\mathrm{RDG} / 2)+1]\}$ is larger than reported $\mathrm{ROE}$, the latter will be smaller than ROE under R\&D capitalization, (namely, conservative reporting), and vice versa for $\{\mathrm{RDG} /[(\mathrm{RDG} / 2)+1]\}<\mathrm{ROE}$. This indeed is the case in the High $\{$ RDG/[(RDG/2)+1]\}-ROE and High RDS portfolio (left-most column): The mean R\&D growth $\{\mathrm{RDG} /[(\mathrm{RDG} / 2)+1]\}$ is $(0.45)$, or $45 \%$, and is substantially larger than the mean reported ROE (-1.266), which in turn is smaller (conservative reporting) than the R\&D-capitalized ROE $(-0.223)$. In the case of Low $\{\mathrm{RDG} /[(\mathrm{RDG} / 2)+1]\}-\mathrm{ROE}$ and High RDS portfolio (third from the right-most column), the mean $\mathrm{R} \& \mathrm{D}$ growth $\{\mathrm{RDG} /[(\mathrm{RDG} / 2)+1]\}$ is $(0.042)$, or $4.2 \%$, and is substantially lower than the mean reported ROE (1.343), which in turn is larger (aggressive reporting) than the $R \& D$-capitalized $\mathrm{ROE}(0.455)$. Thus, in each of the nine portfolios, the

\footnotetext{
12 We thank a reviewer for this suggestion.

${ }^{13}$ Results based on the first variation are very similar to those reported in Table 3 and are available upon request.
} 
empirical relationship between the reported and R\&D-capitalized ROEs is consistent with proposition 1's prediction and the related hypothesis H1. To abstract from extreme observations, we also computed median values (reported in squared brackets in Table 3). Examination of the medians indicates that the expected relationships (reporting biases) hold at the medians too.

The mean and median differences between reported and R\&D-capitalized ROE are presented in the row labeled "Reported ROE minus R\&D-capitalized ROE" with t-statistics in parentheses. All the mean differences but one are significantly different from zero. However, only four out of the nine median differences are significantly different from zero. These significance tests imply that many of the reporting biases are driven by extreme cases.

The remaining data in Table 3 show that high R\&D growth firms are characterized by the lowest book-to-market ratios, reflecting investors' strong growth expectations from high R\&D growth companies. These firms are also characterized by relatively low earnings-to-price ratios, particularly pronounced at the medians. This reflects the depressed reported earnings of these firms as a result of the expensing of $R \& D$. High $R \& D$ growth firms also tend to have high $R \& D$ 
intensity. The differences between the mean and the median firm sizes in each portfolio are large, indicating the existence of very large firms in each portfolio. ${ }^{14}$

Table 4 presents data for the relationship between R\&D growth and earnings momentum (growth) for nine RDG(5)-EM(5) and R\&D-to-sales ranked portfolios, including control for R\&D intensity. As in the R\&D growth and ROE analysis (Table 3), sample firms were first ranked into high, medium, and low five-year R\&D growth minus five-year earnings momentum, RDG(5)-EM(5), portfolios, and then within each of those portfolios into high, medium and low R\&D-to-sales portfolios. We expect (H2) that when $\mathrm{RDG}(5)$ is larger than reported $\operatorname{EM}(5)$, the latter will be smaller than $\operatorname{EM}(5)^{\mathrm{C}}$, and vice versa for $\mathrm{RDG}(5)<\operatorname{EM}(5)$. This indeed is the case in the High RDG(5)-EM(5) and the High RDS portfolio (left-most column), where the mean five-year R\&D growth RDG(5) of 2.771 (277.1\% over five years) is substantially larger than the mean reported five-year earnings change $\operatorname{EM}(5)$ of -7.792 , which in turn is smaller (conservative reporting) than $R \& D$-capitalized earnings momentum, $\operatorname{EM}(5)^{\mathrm{C}}$, of -6.434 . In the case of Low

${ }^{14}$ Based on a reviewer's comment we also allowed for the possibility of a disproportionate R\&D growth in the early years of the five-year period over which R\&D growth is measured. Thus, if in the first two years $R \& D$ growth is very high relative to the last three years, the current ROE may not reflect the expected amount of bias. To alleviate this concern we used a five-year ROE calculated as: $\operatorname{ROE}(5)=\frac{\sum_{\tau=0}^{4}\left[E_{t-\tau}+\left(R^{\tau}-1\right) D_{t-\tau}\right]}{\frac{B V E_{t-5}+B V E_{t}}{2}}$, where E is reported earnings (Compustat item no. 172), D is common dividends (Compustat item no. 21), BVE is book value of equity (Compustat item \# 60), and $\mathrm{R}$ is 1 plus the average discount rate of $12 \%$. The numerator is cum-dividend aggregate earnings over the five-year horizon, i.e. it also includes earnings from the reinvestment of dividends and thus consistent with Ohlson (1995). We formed portfolios by ranking firms on five-year R\&D growth minus five-year ROE, [RDG(5) - ROE(5)], and R\&D-to-sales. The results, available upon request, are very similar to those reported in Table 3: the predicted relationship is still present but the significance of the reporting bias is lower. 
RDG(5)-EM(5) and medium RDS portfolio (second from the right-most column), the mean fiveyear R\&D growth of $0.504,(50.4 \%$ over five years) is substantially lower than the mean reported five-year earnings change $\operatorname{EM}(5)$ of 7.337 , which in turn is larger (aggressive reporting) than the five-year earnings change under R\&D capitalization of 6.872. Thus, our model's predictions regarding the cut-off rates for conservative/aggressive reporting of earnings growth and ROE, are validated by the data.

The data in Table 4 show that the differences between the mean reported earnings momentum and the momentum under R\&D capitalization are in all but two portfolios in the expected direction (the Medium RDG(5)-EM(5) - Low RDS, and the Low RDG(5)-EM(5) High RDS portfolios are in the opposite direction, perhaps due to outliers). Median values (reported in squared brackets in Table 4) exhibit similar patterns to the means. Thus, the empirical relationship between the reported and R\&D-capitalized earnings momentum is generally consistent with proposition 2's prediction and thus with hypothesis H2. However, the mean differences between reported and $R \& D$-capitalized earnings changes (reported in the row labeled "Reported earnings momentum minus R\&D-capitalized earnings momentum") are significant in only two of the nine portfolios ( $t$-statistics in parentheses). None of the median differences between reported and R\&D-capitalized earnings changes are significant. Thus, although the expected patterns are present in the data, the reporting bias in earnings momentum, unlike the bias in ROE, is not material. ${ }^{15}$ A comparison of Tables 3 and 4 reveals that mean and median differences between reported and $R \& D$ capitalized earnings momentum, given $R \& D$ growth and R\&D intensity (Table 4) are larger than the differences between reported and R\&D-

\footnotetext{
$15 \mathrm{We}$ also run the momentum analysis using the first variation of the portfolio approach, i.e. initially classifying firms into three $\operatorname{EM}(5)$ portfolios and then within each $\operatorname{EM}(5)$ portfolio firms were classified into three R\&D growth portfolios. The results of this analysis, available upon request, are stronger than those reported in Table 4, i.e. differences between reported and R\&D-capitalized earnings changes in all nine portfolios are in the expected direction. However, only three mean and median differences are significantly different from zero.
} 
capitalized ROE (Table 3). The reason apparently lies in the larger effect of R\&D capitalization on a change indicator (earnings momentum) than on a levels measure (ROE). ${ }^{16}$

Summarizing, our analyses validate the predictions of our propositions and provide empirical support for the related hypotheses $\mathrm{H} 1$ and $\mathrm{H} 2$ : differences between R\&D growth rates and key profitability measures (earnings momentum and ROE) lead to systematic reporting biases in the profitability measures. In general, companies with high $R \& D$ growth rate relative to their profitability (often emerging industries, such as biotech, and young companies), report conservatively, while low R\&D growth companies (mature firms) report aggressively. The analysis also indicates that the reporting biases are substantially larger for the earnings momentum than for the return on equity. Thus, the widely held view that the expensing of intangible investments generally leads to conservative profitability reporting is a misconception. At the same time the analysis reveals that the reporting bias in ROE is statistically significant in most portfolios while the reporting bias in the earnings momentum (growth) is statistically insignificant in most portfolios. Evidently, the cross-sectional variability of the earnings momentum bias is larger than that of the ROE bias. We now turn to the question: What, if any, are the effects of reporting biases (conservative/aggressive reporting) on investors' valuations?

16 Despite the nonlinearities in the theoretical relationships between the key variables (R\&D growth and profitability measures), we also carried out a regression analysis of reporting biases. Specifically, we regressed for the pooled sample (with time and industry dummy variables) the reporting bias, namely the difference between the firm's reported and R\&D-capitalized earnings momentum, i.e. $\operatorname{EM}(5)-\mathrm{EM}(5)^{\mathrm{C}}$, on the theoretical driver of the bias the difference between R\&D growth and reported earnings momentum, i.e. RDG(5)-EM(5). Additional independent variables are the squared difference between $\mathrm{RDG}(5)$ and $\operatorname{EM}(5)$ (to capture some nonlinearities), log firm size, and R\&D intensity, RDS. A similar regression was run for R\&D growth and ROE, namely ROE $-R^{C}{ }^{C}$ (the ROE reporting bias), regressed on the following variables: $\{\mathrm{RDG} /[(\mathrm{RDG} / 2)+1]\}-\mathrm{ROE},(\{\mathrm{RDG} /[(\mathrm{RDG} / 2)+1]\}-\mathrm{ROE})^{2}$, $\log$ firm size, R\&D intensity, and time and industry dummy variables. The estimated coefficients of the "drivers of reporting biases," namely $\mathrm{RDG}(5)-\mathrm{EM}(5)$ and $\{\mathrm{RDG} /[(\mathrm{RDG} / 2)+1]\}-\mathrm{ROE}$ are negative and highly significant, $(-0.852, t=-42.74)$ and $(-0.441, t=-68.95)$, respectively. These coefficients indicate that when the $R \& D$ growth rate is larger than the earnings momentum, reported momentum tends to become smaller than R\&D-capitalized momentum (conservatism bias), and vice versa for R\&D growth below the earnings momentum (an aggressive bias). Similarly, as predicted by the model, for R\&D growth above ROE, reported ROE will fall short of R\&D-capitalized ROE (conservative bias). 


\section{The Valuation Consequences of Reporting Biases}

\subsection{Methodology}

In this section we examine hypotheses $\mathrm{H} 3$ and $\mathrm{H} 4$, namely whether the reporting biases lead to stock market misvaluations. For this we again employ both regression and portfolio analyses. Our regression methodology is similar to the one used by Lev and Sougiannis (1996) who follow Fama and French (1992) by relating stock returns to lagged values of fundamental variables. In particular, Fama and French (1992) regressed stock returns on lagged values of the following fundamentals: systematic risk $(\beta)$, firm size (market capitalization), the book-tomarket ratio, financial leverage, and the earnings-to-price ratio. Lev and Sougiannis (1996) added to these variables an $R \& D$ intensity measure — the R\&D capital-to-market ratio —and found its coefficient to be positive and highly significant. In this study we add to the model yet another variable relating to the reporting bias in ROE or earnings momentum. We use the variables $\{\mathrm{RDG} /[(\mathrm{RDG} / 2)+1]\}-\mathrm{ROE}$ and $\mathrm{RDG}(5)-\mathrm{EM}(5)$ directly in the regression and we also construct bias score variables as suggested by Fama and MacBeth (1973). Thus, we estimate the following cross-sectional regression:

$$
\begin{aligned}
\mathrm{R}_{\mathrm{i}, \mathrm{t}+\mathrm{j}}= & \mathrm{c}_{0, \mathrm{j}}+\mathrm{c}_{1, \mathrm{j}} \beta_{\mathrm{i}, \mathrm{t}}+\mathrm{c}_{2, \mathrm{j}} \ln (\mathrm{M})_{\mathrm{i}, \mathrm{t}}+\mathrm{c}_{3, \mathrm{j}} \ln (\mathrm{B} / \mathrm{M})_{\mathrm{i}, \mathrm{t}}+\mathrm{c}_{4, \mathrm{j}} \ln (\mathrm{A} / \mathrm{B})_{\mathrm{i}, \mathrm{t}} \\
& +\mathrm{c}_{5, \mathrm{j}}(\mathrm{E}(+) / \mathrm{M})_{\mathrm{i}, \mathrm{t}}+\mathrm{c}_{6, \mathrm{j}}\left(\mathrm{E} / \mathrm{M} \text { dummy }_{\mathrm{i}, \mathrm{t}}+\mathrm{c}_{7, \mathrm{j}} \ln (\mathrm{RDC} / \mathrm{M})_{\mathrm{i}, \mathrm{t}}\right. \\
& +\mathrm{c}_{8, \mathrm{j}}(\mathrm{ROE} \text { or EM bias score })_{\mathrm{i}, \mathrm{t}}+\mathrm{e}_{\mathrm{i}, \mathrm{t}+\mathrm{j}} .
\end{aligned}
$$

Where:

$\mathrm{R}_{\mathrm{i}, \mathrm{t}+\mathrm{j}} \quad=$ returns: monthly stock returns of firm $\mathrm{i}$, starting with the $7^{\text {th }}$ month after fiscal $\mathrm{t}$ year-end, $\mathrm{j}=1, \ldots ., 84$, 
$\beta_{\mathrm{i}, \mathrm{t}} \quad=$ risk: CAPM-based beta of firm $\mathrm{i}$, estimated from 60 monthly stock returns up to month $\mathrm{t}$ (one month preceding the return calculation); a minimum of 24 months is required,

$\mathrm{M}_{\mathrm{i}, \mathrm{t}} \quad=$ size: market value of firm $\mathrm{i}$, calculated as price times number of shares outstanding at $\mathrm{t}$, the beginning of the returns calculation period,

$(\mathrm{B} / \mathrm{M})_{\mathrm{i}, \mathrm{t}} \quad=$ book-to-market: ratio of book value of common equity (Compustat item no. 60$)$ plus balance sheet deferred taxes (Compustat item no. 74) to market value of equity of firm i at fiscal year-end (Compustat item no. 199 times item no. 25),

$(\mathrm{A} / \mathrm{B})_{\mathrm{i}, \mathrm{t}} \quad=$ leverage: ratio of book value of total assets (Compustat item no. 6$)$ to book value of common equity of firm i at fiscal year-end,

$[\mathrm{E}(+) / \mathrm{M}]_{\mathrm{i}, \mathrm{t}} \quad=$ earnings/price ratio: ratio of positive earnings before extraordinary items (Compustat item no. 18) plus income statement deferred taxes (Compustat item no. 50) minus preferred dividends (Compustat item no. 19), to the market value of common equity of firm $i$ at fiscal year-end; this variable is set equal to 0 when earnings are negative,

$(\mathrm{E} / \mathrm{M} \text { dummy })_{\mathrm{i}, \mathrm{t}}=1$ if earnings of firm $\mathrm{i}$ for fiscal $\mathrm{t}$ are negative, and 0 otherwise,

$(\mathrm{RDC} / \mathrm{M})_{\mathrm{i}, \mathrm{t}} \quad=R \& D$ capital: estimated $\mathrm{R} \& \mathrm{D}$ capital [expression (2)] over market value of equity at fiscal year-end,

$(\mathrm{ROE} \text { bias score })_{\mathrm{i}, \mathrm{t}}=\mathrm{ROE}$ bias score: scaled decile rank of $\left(\left\{\mathrm{RDG}_{\mathrm{it}} /\left[\left(\mathrm{RDG}_{\mathrm{it}} / 2\right)+1\right]\right\}\right.$ minus $\left.\mathrm{ROE}_{\mathrm{it}}\right)$, constructed by ranking the values of this difference into deciles $(0,9)$ each year $t$ and dividing the decile number by nine, so that each firm $i$ takes on a decile rank value ranging between zero and one in each year t. The ranking is on an ascending order and thus firms with the most negative $\left(\left\{\mathrm{RDG}_{\mathrm{it}} /\left[\left(\mathrm{RDG}_{\mathrm{it}} / 2\right)+1\right]\right\}\right.$ 
minus $\mathrm{ROE}_{\mathrm{it}}$ ) values are assigned the score of zero while firms with the most positive $\left(\left\{\mathrm{RDG}_{\mathrm{it}} /\left[\left(\mathrm{RDG}_{\mathrm{it}} / 2\right)+1\right]\right\}\right.$ minus $\left.\mathrm{ROE}_{\mathrm{it}}\right)$ values are assigned the score of 1 .

$(\text { EM bias score })_{\mathrm{i}, \mathrm{t}}=$ Earnings Momentum bias score: scaled decile rank of $\left(\mathrm{RDG}(5)_{\mathrm{it}}-\mathrm{EM}(5)_{\mathrm{it}}\right)$, constructed by ranking the values of this difference into deciles $(0,9)$ each year $t$ and dividing the decile number by nine, so that each firm i takes on a decile rank value ranging between zero and one in each year t. The ranking is on an ascending order and thus firms with the most negative $\operatorname{RDG}(5)_{\mathrm{it}}-\operatorname{EM}(5)_{\mathrm{it}}$ values are assigned the score of zero while firms with the most positive $\operatorname{RDG}(5)_{\text {it }}-\operatorname{EM}(5)_{\text {it }}$ values are assigned the score of $1 .^{17}$

The following time-line clarifies the regressions (3):

\section{$\underline{\text { Subsequent returns }}$}

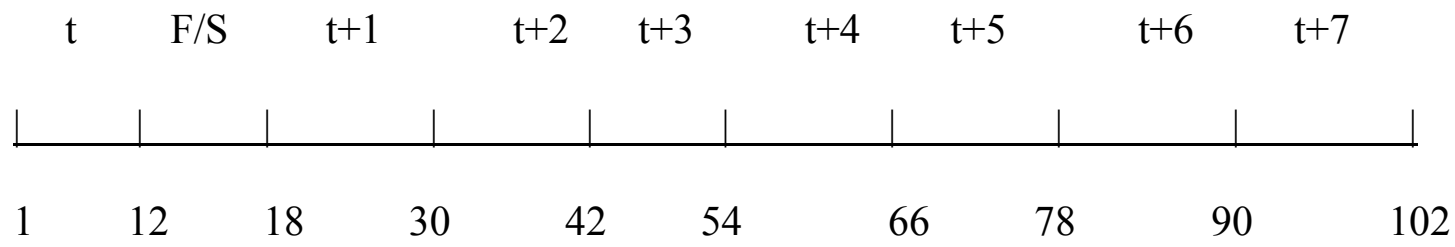

The accounting fundamentals - book value, earnings, total assets, R\&D expenditures, $R \& D$ capital, R\&D growth, ROE and earnings momentum - pertain to fiscal year $t$ (months 1-12 in the time line). Six months (13-18) are then allowed to pass for the public disclosure of fiscal $t$ annual financial statements by all sample firms, followed by 12 first-year monthly stock returns, $\mathrm{R}_{\mathrm{i}, \mathrm{t}+\mathrm{j}}$ (months 19-30), ending up with 12 seventh-year monthly stock returns (months 90-102). For the R\&D growth minus the ROE analysis we have 21 years of portfolio formation (1975-1995) and we estimate regression (3) cross-sectionally for each of the subsequent 84 return months. Thus,

\footnotetext{
${ }^{17}$ In additional analyses we use directly the bias variable in the regression instead of the score variable. The results are similar to those reported but slightly weaker. We also use a score variable for R\&D intensity, i.e. we have both an R\&D intensity score variable and a bias driving score variable. Again, our inferences do not change significantly.
} 
in total, 1,764 cross-sectional regressions were estimated (21 years x 84 regressions per year). For the R\&D growth minus the earnings momentum analysis we have 17 years of portfolio formation (1979-1995), since we need five years to construct $\operatorname{EM(5),~and~we~estimate~regression~}$ (3) cross-sectionally for each of the subsequent 84 return months. Thus, in total, 1,428 crosssectional regressions were estimated (17 years x 84 regressions per year). For this analysis we obtained stock returns, stock prices and shares outstanding from the CRSP monthly files. The portfolio analysis is further explained below.

\subsection{Regression analysis: ROE Biases}

Table 5 reports mean coefficient estimates of regression (3) for the R\&D growth minus ROE analysis. Panel A reports results for subsequent years 1, 3, 5, and 7 for regression (3) without the bias score variable. This benchmark regression gives results very similar to those reported by Lev and Sougiannis (1996 and 1999), and Penman and Zhang (2002) who used it for a horizon up to two years ahead. Here we extend the horizon to seven years ahead and it is interesting to note that the only variable that is highly significant (1\% level) consistently in all years is the $R \& D$ intensity variable $(R D C / M)$. Thus, the ability of $R \& D$ intensity to predict returns is a rather long run phenomenon. This evidence provides support for the risk explanation of the R\&D intensity effect. ${ }^{18}$

Panel B of Table 5 reports the results of regression (3) when the R\&D growth minus ROE bias score is included as an independent variable. The significance of R\&D intensity $(\mathrm{RDC} / \mathrm{M})$ is not diminished, but the bias score variable is significantly negative in year 1 $(-0.0031, \mathrm{t}=-2.602)$. Given the construction of the bias score variable, this result indicates that firms with R\&D growth greater than ROE (for which the score is 1) in year t earn negative

\footnotetext{
${ }^{18}$ The size and book-to-market (B/M) coefficients have signs consistent with those reported in prior studies, negative for size and positive for $\mathrm{B} / \mathrm{M}$, but they are significant only in the early years.
} 
abnormal returns in the next year $(t+1)$. This is an unexpected result because such firms are predicted by our model to be undervalued: their expensing of R\&D leads to conservative reporting, as shown above. ${ }^{19}$ Thus, the expectation was to see a significantly positive coefficient at $\mathrm{t}+1$. The significantly negative coefficient implies that any undervaluation due to the reporting bias at $t$ continues at $t+1$. The question then is: when is this mispricing corrected? Clearly, the correction should manifest in positive bias score coefficients (positive returns) in future years. The panel reports that for year $t+3$ the coefficient is still negative but not significant. However, the coefficient, although insignificant, reverses sign to positive in year 4 (not reported), remains positive in year 5 (reported) and continues to be positive in years 6 (not reported) and 7 (reported). In fact, the sum of the coefficients over the seven year horizon is only -0.0001 (0.00421 in the first three years and 0.0041 in the last four years).

These results suggest that any mispricing caused by the reporting $\mathrm{R} \& \mathrm{D}$-related bias is corrected for different firms at different times, namely the correction spreads over several years. The remaining panels, $\mathrm{C}$ to $\mathrm{H}$, in Table 5 provide corroborating evidence. In panel $\mathrm{C}$ we report results based on the inclusion of the change in the bias score in regression (3). The reasoning is that when the bias driving variable $(\mathrm{RDG} /[(\mathrm{RDG} / 2)+1]\}$ minus $\mathrm{ROE}$ ) changes (sufficiently for the decile score to change), the market notices the change and takes the appropriate action. Indeed, the significance of the bias score coefficient decreases from the $1 \%$ level in panel B to the $5 \%$ level in panel $\mathrm{C}$. The change in the bias score coefficient is positive in both reported years 1 and 2 implying that a correction is taking place. However, the evidence is not strong given the small magnitude and insignificance of this coefficient $(0.0009, \mathrm{t}=0.570$ in year $\mathrm{t}+1)$. This leads us to focus on the most pronounced changes, the reversals, in the bias driving variable

\footnotetext{
${ }^{19}$ We carried out a variety of tests that focused on the level of the bias driving variable or the bias score variable, such as examining the behavior of extreme bias score deciles. Those tests did not yield any insights because, as is demonstrated below, it is not the level but the change in the bias that is relevant for the analysis.
} 
$(\mathrm{RDG} /[(\mathrm{RDG} / 2)+1]\}$ minus $\mathrm{ROE})$. The reason is that when the bias driving variable reverses sign investors notice it and take the appropriate action that corrects the mispricing.

We test this conjecture by explicitly controlling in regression (3) for reversals in the bias driving variable. In particular, we identify firms for which the bias driving variable reversed from positive in year $\mathrm{t}-1$ to negative in year $\mathrm{t}$, and from negative in year $\mathrm{t}-1$ to positive in year $\mathrm{t}$. The bias scores for these two groups of firms are added as two additional explanatory variables in regression (3) and their coefficients capture the incremental effect for each group. The results reported in panel D of Table 5 show for both years 1 and 2 a positive incremental coefficient for the bias reversal from positive to negative, consistent with correction of undervaluation of these firms at $\mathrm{t}$, and a negative coefficient for the bias reversal from negative to positive, consistent with a correction of overvaluation of those firms at $t$. However, although coefficient signs are consistent with mispricing corrections the incremental coefficients are not significant. ${ }^{20}$ The insignificance in this case can be due to the collinearity among the three score variables. We control for this by estimating regression (3) for each reversal group separately. Panels E and F report the results for the positive to negative bias reversal group and the negative to positive reversal group, respectively. The bias score coefficient in panel $\mathrm{E}$ is positive in both years 1 and $2(0.0065$ and 0.0116 , respectively), and larger in magnitude than in previous panels but not significant. In panel $\mathrm{F}$ the bias score coefficient is positive and significant at the $10 \%$ level in year $1(0.0139 \mathrm{t}=2.011)$, opposite to expectation, and negative in year 2 . It is possible there is noise in the data and the statistical power is low due to the relatively small yearly samples (about

\footnotetext{
${ }^{20}$ The reported mean coefficients are simple averages, i.e. equally weighted. We also calculated weighted mean coefficient estimates where the weights used were inversely proportional to the variance of each monthly coefficient estimate as in Chan et al (1991). In both cases we adjusted for serial correlation in the time series of coefficients as in Abarbanell and Bernard (2000). These adjustments did not lead to any more significant statistics or to changes in our inferences.
} 
130 firms per year). ${ }^{21}$ Thus, the results of Table 5 provide only weak support for hypothesis H3. ${ }^{22}$

\subsection{Portfolio Analysis: ROE Biases}

Although in the above regression analysis the bias score coefficients are not statistically significant, their signs are suggestive of systematic corrections taking place when bias reversals occur. We obtain additional insights using the following bias reversal portfolio analysis. In each sample year we select firms for which the difference $(\mathrm{RDG} /[(\mathrm{RDG} / 2)+1]\}$ minus $\mathrm{ROE})$ reverses and form three portfolios: (a) "positive to negative reversal" portfolio, (b) "negative to positive reversal" portfolio, and (c) "Non reversal" portfolio (the remaining firms in the sample). We trace these firms back five years before the reversal and one year after the reversal. For each of these seven years and for each portfolio we compute descriptive statistics and calculate annual raw and abnormal returns. These annual returns are for the year following the disclosure of the financial statements (the returns calculation starts from the seventh month after fiscal year-end). The abnormal returns are the residuals from regression (3) without the bias score variable. We estimate this regression each year for all firms and then calculate the mean residuals for the firms that belong to each portfolio. The advantage of calculating abnormal returns using such a regression is that it allows to control for various well-known risk factors (beta, size, book-tomarket) including R\&D. Obviously, controlling for $R \& D$ is important in isolating a reporting bias effect.

\footnotetext{
${ }^{21} \mathrm{We}$ also examined sub-samples with large (above the median) reversals only, as well as sub-samples of large size firms with also large reversals (highly visible firms). In both cases bias score coefficients were large in magnitude and their signs were consistent with mispricing corrections but they were insignificant. Small sample sizes in these cases can be a reason for insignificant results.

${ }^{22} \mathrm{We}$ also used returns starting with the $4^{\text {th }}$ month (instead of the $7^{\text {th }}$ month) after fiscal $t$ year end to allow for an early reaction, i.e. reaction very soon after annual financial statements are disclosed. Nothing changed in our regression results by doing that.
} 
Table 6 reports the results from this portfolio analysis. Panel A presents the results for the "positive to negative reversal" portfolio. The bias driving variable reported in the first row of the panel shows a strong pattern: for the five years prior to the reversal the bias is consistently positive and almost monotonically increases, then it reverses by a substantial amount and remains negative at $\mathrm{t}+1$. Thus, the bias builds up to a significant positive value before it reverses to a negative value and it takes, on average, six years to reverse. Recall that the expectation for this portfolio is to be undervalued given the presence of conservative accounting. Indeed, both raw and abnormal annual one-year ahead stock returns, reported in the second and third rows of the panel, peak in the year of the reversal. (Note that reported returns are for the year following the disclosure of the financial statements, i.e. returns reported for year t-1 are actually returns earned in year $\mathrm{t}$ ). Thus, raw and abnormal returns in year $\mathrm{t}$ rise to $35.2 \%$ and $13.3 \%$, respectively, and then decline, suggesting that a correction takes place. In particular, the abnormal returns pattern is consistent with an undervaluation of this portfolio: they are negative and large in magnitude in the three early years $(-9.4 \%,-10.6 \%,-12.8 \%)$, close to zero in the year before the reversal $(2.8 \%)$, positive and large in magnitude in the year of the reversal $(13.3 \%)$, and drop to about zero in the last two years $(2 \%,-0.7 \%){ }^{23}$

The remaining data reported in the panel identify the characteristics of the firms in this portfolio. On average, about 140 firms have positive to negative reversals per year during our sample period. Their mean size (market capitalization) is close to $\$ 1$ billion, systematic risk (beta) is well above the market's average risk, and they are growth firms (E/P and B/M ratios below normal). These firms allocate about $6 \%$ of their sales revenues to R\&D (R\&D-to-sales) and their R\&D growth rate is particularly strong in the five years before the reversal. This strong R\&D growth rate leads to an accounting conservative bias (consistent with the above analysis) as

23 These results are consistent with the positive bias score coefficients reported in Table 5, panel E, for firms in this portfolio. 
it is evident in the comparison of reported ROE and adjusted ROE: for the five years before the reversal reported ROE is less than adjusted ROE, while in the year of the reversal and the subsequent one the opposite holds.

Panel B reports the findings for the "negative to positive reversal" portfolio. The bias driving variable shows a declining pattern reaching a large negative value in year $\mathrm{t}-1(-0.281)$ and reversing to a large positive value in year $\mathrm{t}(0.201)$. However, unlike the previous case, the bias in this portfolio reverses in a shorter period of time. The expectation for this portfolio is to be overvalued given the presence of aggressive accounting. Evidence of overvaluation is present in both the raw and abnormal annual stock returns. Thus, in year t-2 raw and abnormal returns reach mean values of $31.9 \%$ and $9.8 \%$, respectively. A reversal is also evident in year $\mathrm{t}$ with mean raw returns declining to $10.5 \%$ and abnormal returns to $-8 \%$. This pattern is consistent with a market correction for this portfolio as well. The remaining data in this panel indicate that, on average, about 130 firms have such reversals per year over the sample period. These firms are smaller in size, more profitable, and with lower R\&D growth than firms in panel A.

Panel C reports the results for the "Non reversal" portfolio. Most of the sample firms belong to this portfolio. The bias driving variable has consistently large positive values similar to those of the "positive to negative reversal" portfolio. However, unlike the other two portfolios, there is no specific pattern in stock returns. Raw and abnormal returns stay around 20\% and $0 \%$ over the seven-year horizon, respectively. This increases our confidence that the patterns observed in the two portfolios described above reflect mispricing and its correction. It is also important to note that the yearly mean returns, especially the abnormal returns, are remarkably consistent with the all years mean returns for each portfolio reported in Table 6 . Thus, the returns results are systematic and not driven by extreme values. 
We summarize this portfolio analysis by plotting the average annual abnormal returns

(AR) for each of the portfolios over the seven-year horizon. Figure 1 shows the three lines: ARNR for the "Non reversal" portfolio, AR-PN for the "positive to negative reversal" portfolio, and AR-NP for the "negative to positive reversal" portfolio. Clearly, the AR-NR line is flat and close to zero. However, AR-NP and AR-PN show patterns consistent with overvaluation and undervaluation, respectively. AR-NP starts negative, increases to about $10 \%$, then declines to $-8 \%$ and converges to $0 \%$ by $\mathrm{t}+2$, indicating a complete correction of the overvaluation. AR-PN starts negative, declines further to about $-13 \%$, then reverses to about $13 \%$ and also converges to $0 \%$ by $\mathrm{t}+2$, indicating a complete correction of the undervaluation. Overall, these portfolio results provide substantial support for our hypothesis $\mathrm{H} 3$.

\subsection{Regression Analysis: Momentum Bias}

Table 7 reports mean coefficient estimates of regression (3) for the R\&D growth minus earnings momentum analysis and its structure is identical to Table 5. In panel A the results from the benchmark regression confirm once again that the only variable that is highly significant in all seven years is the $\mathrm{R} \& \mathrm{D}$ intensity $(\mathrm{RDC} / \mathrm{M})$. In panel $\mathrm{B}$ the $\mathrm{R} \& \mathrm{D}$ growth - earnings momentum bias score variable has a negative but insignificant coefficient in year $1(-0.0020$, $\mathrm{t}=-1.642$ ). This is a similar result to that reported in Table 5, panel $\mathrm{B}$, in terms of sign but not of statistical significance. It indicates that firms with R\&D growth greater than earnings growth (for which the score is 1 ) in year $\mathrm{t}$ earn negative but not significant abnormal returns one year ahead $(t+1)$. The bias score coefficient continues to be negative insignificant in year 2 (not reported) but reverses sign to positive in year 3 , and it is marginally significant at the $10 \%$ level $(0.0023$, $\mathrm{t}=1.674)$. 
The above results suggest that the earnings momentum bias effects (Table 7) appear to be weaker and persist over a shorter period of time than the ROE bias effects (Table 5). Panels $\mathrm{C}$ to $\mathrm{F}$ in Table 7 report evidence consistent with mispricing corrections for different firms at different times (as in Table 5). Thus, in panel $\mathrm{C}$ while the bias score coefficient is negative the change in the bias score coefficient is positive for both years reported. Panel D reports a positive incremental coefficient for the bias reversal from positive to negative $(0.0013, \mathrm{t}=0.179)$, consistent with correction of undervaluation of these firms at $t$, and a significantly at $10 \%$ level negative coefficient for the bias reversal from negative to positive $(-0.0025, \mathrm{t}=-1.794)$, consistent with correction of overvaluation of those firms at $t$. In panel $E$ the bias score coefficient for the positive to negative bias reversal group is positive in both years $1(0.0046$, $\mathrm{t}=0.42)$ and $2(0.0076, \mathrm{t}=0.710)$ and larger in magnitude than in previous panels (but still not significant). In panel $\mathrm{F}$ the bias score coefficient for the negative to positive bias reversal group is negative in both years reported and significant at the $10 \%$ level in year $2(-0.0103$, $\mathrm{t}=-1.903)$. The evidence is consistent with correction of overvaluation but with a delay. ${ }^{24}$ Overall, although the coefficient patterns in Table 7 are similar to those in Table 5, the numbers in the two tables suggest a weaker effect of earnings momentum reporting bias than ROE reporting bias. This is consistent with the insignificant mean and median differences found in Table 4 between reported and R\&D-capitalized earnings momentum. Thus, the results of Table 7 provide only weak support for hypothesis $\mathrm{H} 4 .^{25}$

\footnotetext{
24 This slow reaction can be the result of short selling constraints and transaction costs that delay market correction (limited arbitrage).

${ }^{25} \mathrm{We}$ also ran the regression separately for the following two groups: a) firms with positive to negative large reversals, and b) firms with negative to positive large reversals. Large reversals are defined as those with values above the median reversal value. The coefficients of the earnings momentum bias score variable are still insignificant, but consistent in sign, and larger in magnitude than those reported in panels $\mathrm{E}$ and $\mathrm{F}$ of Table 7.
} 


\subsection{Portfolio Analysis: Momentum Bias}

Table 8 reports results for portfolios formed on the basis of the earnings momentum bias reversals. This analysis is similar to that reported in Table 6. Thus, in each sample year we select firms for which the difference $\operatorname{RDG}(5)_{i t}-\operatorname{EM}(5)_{\text {it }}$ reverses and we form three portfolios: (a) "positive to negative reversal" portfolio, (b) "negative to positive reversal" portfolio, and (c) "Non reversal" portfolio (the remaining firms in the sample). We trace these firms five years before and one year after the reversal year. Panel A reports the results for the "positive to negative reversal" portfolio. The bias driving variable (first raw), on average, reverses within a five year period (positive from $\mathrm{t}-4$ to $\mathrm{t}-1$ and reverses to negative at $\mathrm{t}$ ). The expectation for this portfolio is to be undervalued given the presence of conservative accounting. While the raw returns do not show a strong pattern consistent with undervaluation and correction, the abnormal returns do. (Note that reported returns are for the year following the disclosure of the financial statements, i.e. returns reported for year $\mathrm{t}-1$ are returns earned in year $\mathrm{t}$ ). Thus, abnormal returns rise from $1.3 \%$ in $\mathrm{t}-3$ to $8.2 \%$ and $7 \%$ in years $\mathrm{t}-1$ and $\mathrm{t}$, respectively, and then decline to $0 \%$.

Although the pattern and magnitude of abnormal returns in this case are not as pronounced as the pattern and magnitude in the corresponding ROE bias reversal portfolio (Table 6, panel A), they are still very similar. Both the R\&D and earnings growth rates for this portfolio display high variability over the seven-year horizon (fourth and fifth rows). On average, about 130 firms have such positive to negative reversals per year over our sample period. These are not likely to be firms with a similar ROE bias reversal since they are larger in size (market capitalization close to $\$ 1.5$ billion), they have lower systematic risk (beta), stronger growth (lower $\mathrm{E} / \mathrm{P}$ and $\mathrm{B} / \mathrm{M}$ ratios), and they are more $\mathrm{R} \& \mathrm{D}$ intensive (higher $\mathrm{R} \& \mathrm{D}$-to-sales ratios) than the ROE reversal firms. A more direct comparison is described below. 
Panel B reports the results for the "negative to positive reversal" portfolio. Again, the bias driving variable (first raw), on average, reverses within a five year period. It shows a declining pattern reaching a large negative value in year $t-1(-5.817)$ and reversing to a large positive value in year $\mathrm{t}$ (4.527). The expectation for this portfolio is to be overvalued given the presence of aggressive accounting. Evidence of overvaluation and correction are present in both raw and abnormal annual stock returns. Thus, while prior to the reversal year raw returns are large and positive $(30.4 \%, 24.6 \%, 26.7 \%)$, they decline in year $\mathrm{t}(11 \%)$. Abnormal returns are positive prior to the reversal year $(9 \%, 4.8 \%, 5 \%)$, negative in the reversal year $t(-3.6 \%)$, and then about $0 \%$. This pattern is consistent with a market correction in this case as well. The remaining data in this panel indicate that, on average, about 118 firms have such reversals per year over our sample period. These firms have more stable R\&D growth rates than the firms in panel A but have highly variable earnings growth rates. They are somewhat smaller in size but they have similar systematic risk, E/P, B/P and R\&D intensity as the firms in panel A.

Panel C reports the results for the "Non reversal" portfolio of about 580 firms. Unlike the other two portfolios, there is no systematic pattern in the stock returns. Raw returns and abnormal returns stay around $16 \%$ and $-1 \%$ over the seven-year horizon, respectively. Thus, the results in this panel are similar to those in Table 6, panel C. Overall, the results of Table 8 indicate that the earnings momentum bias affects investor behavior.

As we did with the ROE bias portfolio analysis, we summarize the earnings momentum portfolio analysis by plotting the average annual abnormal returns (AR) for each of the three portfolios over the seven-year horizon. Figure 2 shows the three lines: AR-NR for the "Non reversal" portfolio, AR-PN for the "positive to negative reversal" portfolio, and AR-NP for the "negative to positive reversal" portfolio. All the lines show a pattern consistent with our expectations. Thus, the AR-NR line is rather flat and close to zero. The AR-NP line shows a 
clear overvaluation and a subsequent correction pattern: starting positive, declining to negative values and converging to zero. The AR-PN line shows the opposite pattern: an initial undervaluation, then abnormal returns building up to positive values and converging to zero, consistent with a correction. Overall, these portfolio results indicate that the earnings momentum bias variable has valuation implications and thus provide support for our hypothesis $\mathrm{H} 4$.

\subsection{Firms with simultaneous ROE and earnings momentum bias reversals}

The above analysis is based on either the ROE or the earnings momentum reversal analysis. However, it is possible that for some sample firms reversals in both ROE and earnings momentum biases occur in the same year. This can be an interesting sub-sample to examine because firms with such reversals potentially become more visible to investors and thus we expect to detect more pronounced returns patterns than those presented above.

Table 9 reports the results from the simultaneous ROE and earnings momentum bias reversal analysis for two portfolios: "positive to negative reversal" portfolio in panel A, and "negative to positive reversal" portfolio in panel B. On average, about 30 firms have such simultaneous reversals per year over our sample period. This is about $22 \%$ of firms with either type of reversal reported in panels A and B of Tables 6 and 8 . In addition, these firms have higher $\mathrm{E} / \mathrm{P}$ ratios relative to the sample firms and are of average size. In both panels $\mathrm{A}$ and $\mathrm{B}$ of Table 9 the patterns of both raw and abnormal returns are consistent with initial misvaluation and subsequent correction. Thus, in panel A the returns keep increasing up to year $t$ and then decline, suggesting that a correction takes place. In particular, the abnormal returns pattern is consistent with the undervaluation of this portfolio: the returns are large negative in the three early years $(-7.6 \%,-9.3 \%,-4.9 \%)$, large positive in the following two years including the year of the

reversal $(10.2 \%, 13 \%)$, and stay low after the reversal year $(0.7 \%,-2.8 \%)$. The opposite pattern 
appears in panel B, consistent with an initial overvaluation and subsequent correction: large positive abnormal returns in the three early years $(10.9 \%, 3.3 \%, 12.5 \%)$, and negative in the following three years $(-1 \%,-7.1 \%,-2.6 \%)$.

In Figure 3 we plot the average annual abnormal returns (AR) for each of the two portfolios over the seven-year horizon. The line for the "positive to negative reversal" portfolio, AR-PN, starts and stays negative for three consecutive years indicating strong undervaluation, then it become positive (reverses) and converges to $0 \%$ consistent with complete correction. The line for the "negative to positive reversal" portfolio, AR-NP, displays the opposite pattern: starts and stays positive for three consecutive years, indicating strong overvaluation, then becomes negative (reverses) and converges to about $0 \%$ by $\mathrm{t}+1$. The opposite movement in the two lines is clear and consistent with undervaluation in one case and overvaluation in the other. ${ }^{26}$ The evidence from these two specific portfolios provides strong support for our hypotheses H3 and H4.

\subsection{Sensitivity analysis}

We carried out additional analyses to examine the sensitivity of the results reported above. First, we used a three-year earnings growth rate calculation rather than five, with essentially identical results. In addition, since growth rates the way we calculate them above can be noisy (excessive weight is placed on the first and last observations), we also used the method employed by Dechow and Sloan (1997) that smoothes the calculation. ${ }^{27}$ Only marginal

\footnotetext{
26 We also estimated future returns regressions, as in Tables 5 and 7, for each of these two portfolios. None of the estimated coefficients was significant, most likely due to the low yearly sample size in these two portfolios.

However, the coefficients of the bias score variable were large (above 1\%) and consistent with undervaluation/overvaluation corrections: positive for the "positive to negative reversal" portfolio and negative for the "negative to positive reversal" portfolio.

27 Under this method we fit a least squares growth line to the logarithms of the five annual earnings or R\&D observations.
} 
improvements appeared in some regression results. Second, we examined whether large mergers and acquisitions have an impact on our results by identifying sample firms with at least 50\% change in annual sales. We detected 1,558 such large mergers over our sample period. Of those, 177 are for firms that belong to our "positive to negative reversal" portfolio, i.e. about 9 firms per year on average, and 142 are for firms that belong to our "negative to positive reversal" portfolio, i.e. about 7 firms per year on average. We did not detect any large mergers in our “simultaneous ROE and earnings momentum reversal” portfolio. We rerun both the regression and portfolio analyses excluding the firms with large mergers, and observed minor changes in the results, but our inferences did not change. Third, we controlled for price momentum, documented by Jegadeesh and Titman (1993) among others, by including in our regressions (3) the returns for the six months before portfolio formation. Neither the regression nor the portfolio results were affected by this change, and thus our inferences are not altered. ${ }^{28}$

\section{Summary and conclusions}

We ask in this study: When is the immediate expensing of R\&D (current GAAP) conservative and when is it aggressive, relative to reporting under R\&D capitalization, and what are the capital market implications of these reporting biases? To address these questions we construct a model of profitability reporting biases and identify that the key drivers of the reporting biases are: the differences between R\&D growth rate and earnings (change)

\footnotetext{
${ }^{28} \mathrm{We}$ also run the regression analyses using $\mathrm{R} \& \mathrm{D}$ expenditures-to-market $(\mathrm{RD} / \mathrm{M})$ as a measure of R\&D intensity instead of R\&D capital-to-market (RDC/M) and compared the two sets of results. This allows us to examine whether future stock returns are correlated more with R\&D expenditures (flows) than with underlying R\&D assets (stocks). The RD/M coefficients are consistently positive and significant, consistent with the results of Chan et al (2001). Comparing the RD/M and RDC/M coefficients reveals that the RDC/M coefficients are always larger and with higher t-statistics than the $\mathrm{RD} / \mathrm{M}$ coefficients. In addition, both the ROE and earnings momentum bias score coefficients obtain higher values and significance when $\mathrm{RD} / \mathrm{M}$ is in the regressions. These results suggest that the market places higher weights on capitalized $R \& D$ values than in expensed $R \& D$ values. In other words, stock prices reflect $R \& D$ expenditures as if they has been capitalized and amortized, i.e. as if investors price an intangible asset. This is consistent with evidence provided by Lev et al (2002) and Healy et al (2002).
} 
momentum, and between R\&D growth and ROE. In general, companies with a high growth rate of $R \& D$ relative to their profitability (typically early life cycle companies) report conservatively, while firms with a low $R \& D$ growth rate relative to profitability (mature companies) tend to report aggressively.

In our initial empirical analyses we validate the predictions of the model on a large sample of firms. Thus, profitability reporting biases are present in the data and they appear to be more significant for ROE, relative to $\mathrm{R} \& \mathrm{D}$ growth, than for the earnings momentum. We then analyze the stock returns of the sample firms to examine whether investor valuations are affected by the profitability reporting biases. We find evidence consistent with investor fixation on the reported profitability measures. Thus, the stocks of conservatively reporting firms appear to be undervalued while the stocks of aggressively reporting firms are overvalued, and these misvaluations appear to be corrected when the reporting bias reverses from conservative to aggressive, or vice versa. In addition, the misvaluations appear to be more significant for ROE than for the earnings momentum indicator.

The social relevance of systematic mispricing of securities is that it leads to misallocation of resources at both the real and capital markets. Systematic undervaluations of stocks, for example, implies that the underpriced firms are burdened with excessive cost of capital, leading to suboptimal investment and stunted growth. In the capital markets, mispricing of securities cause wealth transfers between current and new shareholders. Alleviating mispricing is obviously beneficial to firms, shareholders, and society at large. In closing, we should note, however, that there is no assurance that a GAAP requirement for the capitalization of R\&D will eliminate all the current mispricings, although the preliminary evidence (e.g., Aboody and Lev, 1998) is encouraging. 


\section{References}

Abarbanell, J. and V. Bernard, 2000, Is the U.S. Stock Market Myopic? Journal of Accounting Research,38, 221-242.

Aboody, D. and B. Lev, 2000, Information Asymmetry, R\&D, and Insider Gains, Journal of Finance, 55, 2747-2766.

Aboody, D. and B. Lev, 1998, The Value-Relevance of Intangibles: The Case of Software Capitalization, Journal of Accounting Research,36, 161-191.

Barberis, N. and R. Thaler, 2003, A Survey of Behavioral Finance, Chapter 18 in Handbook of the Economics of Finance, Edited by G.M. Constantinides, M. Harris and R. Stulz, Elsevier Science B.V.

Beaver, W. and S. Ryan, 2000, Biases And Lags In Book Value And Their Effect On The Ability Of The Book-To-Market Ratio To Predict Book Return On Equity, Journal of Accounting Research, 38, 127-148.

Chambers, D., R. Jennings and R.B. Thompson, 2002, Excess Returns to R\&D-Intensive Firms, Review of Accounting Studies 7, 133-158.

Chan, K.C.L., Y. Hamao and J. Lakonishok, 1991, Fundamentals and Stock Returns in Japan, Journal of Finance, 46, 1739-1764.

Chan, K.C.L., J. Lakonishok and T. Sougiannis, 2001, The Stock Market Valuation of Research and Development Expenditures, Journal of Finance, 56, 2431-2456.

Danielson, M.G. and E. Press, 2004, The Effect of R\&D Expense on Profitability, Working paper, Temple University.

Dechow M. P., and R.G. Sloan, 1997, Returns to Contrarian Investment Strategies: Tests of Naive Expectations Hypothesis, Journal of Financial Economics, 43, 3-27.

Eberhart, A.C., W.F. Maxwell and A.R. Siddique, 2004, An Examination of Long-Term Abnormal Stock Returns and Operating Performance Following R\&D Increases, Journal of Finance, 59, 623-650.

Fama, E. and J. MacBeth, 1973, Risk, Return and Equilibrium: Empirical Tests, Journal of Political Economy, 81, 607-636.

Fama, E. and K. French, 1992, The Cross-section of Expected Stock Returns, Journal of Finance, 47, 427-65.

Hall, B.H., C. Cummings, E.S. Laderman and J. Mundy, 1988, The R\&D Master File Documentation, NBER technical working paper 72 . 
Healy, P.M., S.C. Myers and C. D. Howe, 2002, R\&D Accounting and the Tradeoff Between Relevance and Objectivity, Journal of Accounting Research, 40, 677-710.

Jegadesch, N. and S. Titman, 1993, Returns to Buying Winners and Selling Losers: Implications for Stock Market Efficiency, Journal of Finance, 48, 65-91.

Keynes, J., 1936, General Theory of Employment, Interest and Money, New York: Harcourt Brace.

Kothari, S.P., T.E. Laguerre and A.J. Leone, 2002, Capitalization versus Expensing: Evidence on the Uncertainty of Future Earnings from Capital Expenditures versus R\&D Outlays. Review of Accounting Studies 7, 355-382.

Lev, B., 1999, R\&D and Capital Markets, Journal of Applied Corporate Finance, 11, 21-35.

Lev, B. and T. Sougiannis, 1996, The Capitalization, Amortization, And Value-Relevance Of R\&D, Journal of Accounting and Economics, 21, 107-138.

Lev, B. and T. Sougiannis, 1999, Penetrating the Book-to-Market Black Box: The R\&D Effect, Journal of Business Finance and Accounting, 26, 419-449.

Lev, B., D. Nissim and J. Thomas, 2002, On the Informational Usefulness of R\&D Capitalization and Amortization, Working paper, Columbia University and New York University.

Luft, J.L. and M. D. Shields, 2001, Why Does Fixation Persist? Experimental Evidence on the Judgment Performance Effects of Expensing Intangibles, The Accounting Review, 76, 561-587.

Monahan, S., 1999, Conservatism, Growth and the Role of Accounting Numbers in the Equity Valuation Process, Working paper, University of Chicago.

Ohlson, J., 1995, Earnings Book Values and Dividends in Security Valuation, Contemporary Accounting Research 11, 661-688.

Penman, S.H. and X. Zhang, 2002, Accounting Conservatism, the Quality of Earnings, and Stock Returns, The Accounting Review, 77, 237-264.

Porter, M. and S. Stern, 1999, The New Challenge to America's Prosperity, Council on Competitiveness, Washington, D.C. 


\section{$\underline{\text { Appendix A }}$}

If the growth rate of $R \& D$ expense is zero, then after a full amortization cycle is complete, both capitalizing and expensing firms will have the same earnings but the capitalizing firm will have more assets and thus lower ROA (or ROE). To see this, set $\mathrm{g}=0$ and notice that as in the example, both firms have the same income in years $\mathrm{t} \geq \mathrm{T}$ but the assets/equity of the capitalizing firm is higher in all periods after T:

$$
B V A_{n}{ }^{c}=B V A_{n}+\sum_{i=1}^{T-1}\left[\frac{i C}{T}\right]=B V A_{n}+\left[\frac{T(T-1)}{2}\right] C
$$

Thus, the capitalizing firm has a lower return on assets in any year $\mathrm{t}<\mathrm{T}$. The argument for return on equity is similar after adjusting for the tax rate.

The extension of this result to the case where the growth rate is non-zero involves the observation that as long as the depreciation pattern used by the firm is stable, the unrecorded R\&D asset also grows at the rate g. $^{29}$ That is, denoting the (unrecorded) R\&D asset at time $\mathrm{n}$ by RD_CAPn, the asset in year $\mathrm{n}+1$ will be $(1+\mathrm{g})$ RD_CAPn. The consequences for ROE may now be derived. First, by definition, $B V A_{n}{ }^{c}=B V A_{n}+R D_{-} C A P_{n}$. Second, we have the following relationship between earnings in year $\mathrm{n}$ measured under the two different accounting methods:

$E_{n}{ }^{c}=E_{n}+(1-\tau)\left\{R D_{-} C A P_{n}-R D_{-} C A P_{n-1}\right\}=E_{n}+(1-\tau) g R D_{-} C A P_{n-1}$

Combining these results, we obtain a result linking the growth rate of expenditures and the decision to capitalize or expense these expenditures with the reported return on assets and equity.

\footnotetext{
${ }^{29}$ By a stable pattern of depreciation, we mean that for an asset of value A bought in year $t$, the depreciation in year $\mathrm{t}+\mathrm{n}$, denoted by $*_{t, n} \mathrm{~A}$, is independent of the date of purchase, $\mathrm{t}$. We are thankful to an anonymous referee for bringing this approach to our attention. Under an assumption of straight-line depreciation, a closed-form expression can be derived for this unrecorded asset as we showed in an earlier version of this paper.
} 
Before deriving this result we state a simple but useful fact as a separate lemma mainly for ease of reference.

\section{Lemma 1}

Suppose $y+z>0$ and $z>0$. Then for any $x, y, \frac{(x+w)}{(y+z)} \geq \frac{x}{y} \Leftrightarrow \frac{x}{y} \geq \frac{w}{z}$.

\section{Proof}

Cross-multiplying and using the fact that $y+z$ and $z$ are positive, we obtain:

$$
\frac{(x+w)}{(y+z)} \geq \frac{x}{y} \Leftrightarrow x+w \geq x+\frac{x z}{y} \Leftrightarrow w \geq \frac{x z}{y} \Leftrightarrow \frac{w}{z} \geq \frac{x}{y} .
$$

Q.E.D

\section{Proof of Proposition 1}

Let:

$$
\begin{aligned}
& x=E_{n} \quad w=(1-\tau) g R D_{-} C A P_{n-1} \quad y=\frac{B V A_{n}+B V A_{n-1}}{2} \\
& z=\frac{B V A_{n}{ }^{c}+B V A_{n-1}{ }^{c}}{2}-\frac{B V A_{n}+B V A_{n-1}}{2}=\frac{R D_{-} C A P_{n}+R D_{-} C A P_{n-1}}{2}=R D_{-} C A P_{n-1}\left(1+\frac{g}{2}\right)
\end{aligned}
$$

Substituting for $E_{n}{ }^{c}$ and $B V A_{t}^{c}$ from the identities derived earlier, Lemma 1 shows that:

$$
\begin{gathered}
R O A_{n}=\frac{E_{n}}{1 / 2\left(B V A_{n}+B V A_{n-1}\right)} \geq \frac{E_{n}{ }^{c}}{1 / 2\left(B V A_{n}{ }^{c}+B V A_{n-1}^{c}\right)}=\frac{E_{n}+w}{1 / 2\left(B V A_{n}+B V A_{n-1}\right)+z} \\
\Leftrightarrow \frac{E_{n}}{1 / 2\left(B V A_{n}+B V A_{n-1}\right)} \geq \frac{w}{z} \\
\Leftrightarrow \frac{E_{n}}{1 / 2\left(B V A_{n}+B V A_{n-1}\right)} \geq \frac{(1-\tau) g}{1+\frac{1}{2} g}
\end{gathered}
$$

Note that in the expressions above, $y, z$, and $y+z$, are all positive as required in Lemma 1 . This establishes the result of the proposition for ROA. The analogous criterion for ROE is 
$R O E_{n} \geq g /(1+g / 2)$. To see this, note that the difference in the book value of equity is $(1-\tau) \mathrm{z}$

(where $\mathrm{z}$ is as defined in the proposition). Thus the analogous ratio is $\mathrm{w} /(1-\tau) \mathrm{z}$ yielding the required result. Q.E.D

Proposition 1 compares return on assets and returns on equity across policies of expensing and capitalizing expenditures. The intuition underlying the finding is a straightforward: under positive expenditure growth, the earnings under expensing, $E_{n}$, is always less than that under capitalization, $E_{n}^{c}$; however, the total assets (or equity) also increases under capitalization and the question then becomes of whether the numerator increase outweighs the denominator increase. The criterion stated in the proposition provides a simple relationship between the growth rate of earnings and the growth rate of expenditures that characterizes when a policy of expensing R\&D might lead to higher reported ratios. At a growth rate of zero, there is no effect on the numerator and it is always better to expense. As the growth rate becomes increasingly positive, the gain in reported income outweighs the increase in assets/equity resulting in a higher ROA/ROE under capitalization. This intuition is straight-forward; the interest in the proposition stems from the simplicity of the cutoff point where capitalization increases ROA, and in particular, that this cutoff does not depend on the length of the amortization cycle.

\section{Proof of Proposition 2}

Let $E_{\mathrm{n}}$ represent the earnings of the firm that expenses R\&D and $E M_{n}=\frac{E_{n}-E_{n-1}}{E_{n-1}}$ represent the earnings growth of this firm. Then the earnings of the capitalizing firm, $E_{n}{ }^{c}$ is given by:

$$
\begin{aligned}
E_{n}{ }^{c}= & E_{n}+(1+g) X \quad E_{n-1}{ }^{c}=E_{n-1}+X \\
& \text { Where : } \quad X=R D_{-} C A P_{n-1}
\end{aligned}
$$


Therefore, the earnings growth of the firm that capitalizes R\&D, denoted $E M_{\mathrm{n}}{ }^{\mathrm{c}}$, is given by:

$$
E M_{n}{ }^{c}=\frac{E_{n}{ }^{c}-E_{n-1}{ }^{c}}{E_{n}{ }^{c}}=\frac{\left(E_{n}-E_{n-1}\right)+[X(1+g)-X]}{E_{n-1}+X}=\frac{\left(E_{n}-E_{n-1}\right)+X g}{E_{n-1}+X}
$$

Using the lemma stated earlier with $x=\left(E_{n}-E_{n-1}\right), y=X g, w=E_{n-1}, z=X$, we obtain: $E M_{n} \geq E M_{n}{ }^{c} \Leftrightarrow E M_{n} \geq g$ (notice that we need $E_{n}{ }^{c}>0$ to apply the lemma).

$$
\text { Q.E.D }
$$

As we showed explicitly in the example, if the growth rate in $R \& D$ expenditures is positive, earnings are always higher under capitalization. The same intuition shows that for any positive growth rate in R\&D expenditures, the earnings change, $E_{n}-E_{n-1}$ is greater under capitalization. The result in Proposition 3 shows that under high earnings growth and low expense growth, the reduction in the denominator, $E_{n-1}$, under expensing is proportionately greater than the reduction on the earnings change $E_{n}-E_{n-1}$ found in the numerator. For firms with these growth characteristics, earnings growth is overstated under a policy of expensing $R \& D$ expenditures. 
Table 1

\section{Sample Summary Statistics}

For selected fiscal years from 1975 to 1995, the data indicate total R\&D expenditure (the GAAP expense) as well as R\&D amortization and R\&D capital, calculated for all U.S. firms engaged in R\&D and listed on NYSE, Amex and Nasdaq with valid data on the Compustat files. The R\&D data are expressed as a percentage of: sales, earnings, and book value of equity. Percentages are computed by adding numerator and denominator data across all companies (i.e., weighted averages).

\begin{tabular}{|c|c|c|c|c|c|c|c|c|}
\hline \multirow[b]{2}{*}{ Year } & \multicolumn{3}{|c|}{$\begin{array}{l}\text { R\&D expenditures (and accounting } \\
\text { expense) as percent of : }\end{array}$} & \multicolumn{3}{|c|}{ R\&D amortization as percent of: } & \multirow{2}{*}{$\begin{array}{c}\text { R\&D capital as } \\
\text { percent of } \\
\text { book value }\end{array}$} & \multirow{2}{*}{$\begin{array}{c}\text { Number } \\
\text { of } \\
\text { firms }\end{array}$} \\
\hline & Sales & Earnings & Book value & Sales & Earnings & Book value & & \\
\hline 1975 & 1.70 & 36.1 & 4.13 & 0.86 & 18.14 & 2.08 & 10.55 & 1,280 \\
\hline 1980 & 1.78 & 34.4 & 5.08 & 1.15 & 22.13 & 3.27 & 12.55 & 1,282 \\
\hline 1985 & 3.01 & 83.7 & 8.11 & 2.14 & 59.71 & 5.79 & 21.25 & 1,668 \\
\hline 1990 & 3.40 & 79.4 & 9.59 & 2.61 & 60.86 & 7.35 & 25.76 & 1,665 \\
\hline 1995 & 3.75 & 65.3 & 10.88 & 2.90 & 50.42 & 8.41 & 28.73 & 1,796 \\
\hline 2000 & 4.54 & 96.9 & 9.22 & 3.36 & 71.86 & 6.83 & 24.90 & 3,569 \\
\hline
\end{tabular}

Notes:

R\&D expenditures (RD) is Compustat item \# 46.

Sales is Compustat item \# 12.

Earnings is Compustat item \# 172.

Book value is Compustat item \# 60.

$\mathrm{R} \& \mathrm{D}$ amortization for firm $\mathrm{i}$ at time $\mathrm{t}$ is equal to $0.2 *\left(\mathrm{RD}_{i t-1}+\mathrm{RD}_{i t-2}+\mathrm{RD}_{i t-3}+\mathrm{RD}_{i t-4}+\mathrm{RD}_{i t-5}\right)$.

$\mathrm{R} \& \mathrm{D}$ capital for firm $\mathrm{i}$ at time $\mathrm{t}$ is equal to $\mathrm{RD}_{i t}+0.8 \times \mathrm{RD}_{i t-1}+0.6 \times \mathrm{RD}_{i t-2}+0.4 \times \mathrm{RD}_{i t-3}+0.2 \times \mathrm{RD}_{i t-4}$. 
Table 2

Median Growth Rates of R\&D and Earnings and the Values of ROE for Selected Industries

(Growth Rates are Measured over Five Years and Presented as Percentages)

\begin{tabular}{|c|c|c|c|c|c|c|c|c|c|c|c|c|c|}
\hline & & \multicolumn{4}{|c|}{ Five-year R\&D Growth } & \multicolumn{4}{|c|}{ Five-year Earnings Growth } & \multicolumn{4}{|c|}{ Return on Equity } \\
\hline SIC & Industry & 1985 & 1990 & 1995 & 2000 & 1985 & 1990 & 1995 & 2000 & 1985 & 1990 & 1995 & 2000 \\
\hline 737 & $\begin{array}{l}\text { Computer programming, } \\
\text { software \& services }\end{array}$ & 124.8 & 31.4 & 100.8 & 100.8 & 74.5 & 32.7 & 75.5 & 98.0 & 11.3 & 2.8 & 7.9 & -27.0 \\
\hline 283 & $\begin{array}{l}\text { Drugs \& } \\
\text { pharmaceuticals }\end{array}$ & 85.8 & 111.3 & 85.4 & 81.0 & 33.4 & 57.4 & 25.6 & 18.0 & 12.1 & 2.4 & 1.6 & -26.0 \\
\hline 357 & $\begin{array}{l}\text { Computers } \\
\text { equipment }\end{array}$ \& office & 82.7 & 55.7 & 33.3 & 68.0 & 29.8 & 21.3 & 53.3 & 8.8 & 8.8 & 6.4 & 9.5 & -1.9 \\
\hline 38 & $\begin{array}{l}\text { Measuring } \\
\text { instruments }\end{array}$ & 71.0 & 36.2 & 31.5 & 56.7 & 16.4 & 45.7 & 54.4 & 40.4 & 9.3 & 8.4 & 8.8 & 3.6 \\
\hline 36 & $\begin{array}{l}\text { Electrical equipment } \\
\text { excluding computers }\end{array}$ & 81.6 & 33.7 & 44.4 & 89.0 & -19.9 & 14.4 & 119.4 & 99.5 & 9.0 & 4.7 & 12.5 & 4.1 \\
\hline 48 & Communications & 123.9 & -7.2 & 6.5 & 19.0 & -91.6 & 105.2 & -47.0 & 97.7 & 1.0 & 18.1 & 4.5 & -9.7 \\
\hline 37 & $\begin{array}{l}\text { Transportation } \\
\text { equipment }\end{array}$ & 49.9 & 24.0 & 46.6 & 51.9 & 89.8 & 2.2 & 166.8 & 43.4 & 13.3 & 9.5 & 17.1 & 14.4 \\
\hline
\end{tabular}

Notes:

R\&D growth equals $\left(\mathrm{RD}_{\mathrm{t}}-\mathrm{RD}_{\mathrm{t}-4}\right) / \mathrm{RD}_{\mathrm{t}-4}$, where $\mathrm{RD}$ is $\mathrm{R} \& \mathrm{D}$ expenditures - Compustat item \# 46.

Earnings Growth equals (earnings $\mathrm{t}_{\mathrm{t}}$ - earnings $\mathrm{s}_{\mathrm{t}-4}$ )/|earnings $\mathrm{s}_{\mathrm{t}-4} \mid$, where earnings is Compustat item \# 172.

Return on equity equals earnings $/$ /Average book value of equity at $\mathrm{t}-1$ and $\mathrm{t}$. Book value of equity is Compustat item \# 60 . 


\section{Table 3}

\section{ROE Biases: Reported versus R\&D capitalized ROE values}

Mean and Median values of various variables for portfolios ranked by annualized R\&D growth $\{\mathrm{RDG} /[(\mathrm{RDG} / 2)+1]\}$ minus one year ROE and R\&D to sales (RDS). Median values are in square brackets. Numbers in parentheses are t-statistics. The sample consists of 32,336 firm-year observations evenly allocated to the nine portfolios.

\begin{tabular}{|l|c|c|c|c|c|c|c|c|c|}
\hline $\begin{array}{l}\text { Annualized R\&D growth } \\
\text { minus one year ROE }\end{array}$ & \multicolumn{3}{|c|}{ High } & \multicolumn{3}{c|}{ Medium } & \multicolumn{3}{c|}{ Low } \\
\hline R\&D to Sales (RDS) & High & Medium & Low & High & Medium & Low & High & Medium & Low \\
\hline Annualized R\&D Growth & 0.450 & 0.460 & 0.408 & 0.165 & 0.149 & 0.139 & 0.042 & 0.007 & -0.038 \\
$\{$ RDG/[RDG/2)+1]\} & {$[0.368]$} & {$[0.419]$} & {$[0.390]$} & {$[0.167]$} & {$[0.151]$} & {$[0.142]$} & {$[0.029]$} & {$[0.015]$} & {$[-0.026]$} \\
\hline Annualized R\&D Growth & 1.716 & 0.860 & 1.071 & 0.078 & 0.060 & 0.054 & -1.302 & -0.363 & -0.334 \\
minus one year ROE & {$[0.848]$} & {$[0.464]$} & {$[0.435]$} & {$[0.075]$} & {$[0.050]$} & {$[0.043]$} & {$[-0.135]$} & {$[-0.130]$} & {$[-0.166]$} \\
\hline R\&D to Sales (RDS) & 6.477 & 0.077 & 0.018 & 0.134 & 0.029 & 0.008 & 0.454 & 0.018 & 0.005 \\
& {$[0.265]$} & {$[0.074]$} & {$[0.016]$} & {$[0.081]$} & {$[0.028]$} & {$[0.008]$} & {$[0.060]$} & {$[0.017]$} & {$[0.005]$} \\
\hline Reported ROE (ROE) & -1.266 & -0.400 & -0.663 & 0.088 & 0.089 & 0.085 & 1.343 & 0.370 & 0.296 \\
& {$[-0.408]$} & {$[0.021]$} & {$[0.021]$} & {$[0.099]$} & {$[0.105]$} & {$[0.105]$} & {$[0.182]$} & {$[0.154]$} & {$[0.146]$} \\
\hline R\&D-Capitalized ROE & -0.223 & -0.058 & -0.199 & 0.102 & 0.096 & 0.087 & 0.455 & 0.129 & 0.224 \\
(ROE C) & {$[-0.135]$} & {$[0.076]$} & {$[0.048]$} & {$[0.116]$} & {$[0.110]$} & {$[0.107]$} & {$[0.127]$} & {$[0.137]$} & {$[0.138]$} \\
\hline Reported ROE minus R\&D- & -1.032 & -0.339 & -0.462 & -0.022 & -0.008 & -0.003 & 0.881 & 0.241 & 0.071 \\
Capitalized ROE & $(-8.805)$ & $(-6.808)$ & $(-4.154)$ & $(-9.013)$ & $(-18.999)$ & $(-8.762)$ & $(2.271)$ & $(3.680)$ & $(1.322)$ \\
(ROE-ROEC) & {$[-0.240]$} & {$[-0.061]$} & {$[-0.022]$} & {$[-0.015]$} & {$[-0.005]$} & {$[-0.001]$} & {$[0.029]$} & {$[0.013]$} & {$[0.005]$} \\
& $(-2.05)$ & $(-1.225)$ & $(-0.198)$ & $(-6.244)$ & $(-12.488)$ & $(-3.155)$ & $(0.075)$ & $(0.199)$ & $(0.094)$ \\
\hline Book-to-Market & 0.383 & 0.477 & 0.421 & 0.667 & 0.893 & 0.924 & 0.219 & -0.111 & 0.615 \\
& {$[0.262]$} & {$[0.456]$} & {$[0.675]$} & {$[0.557]$} & {$[0.765]$} & {$[0.932]$} & {$[0.415]$} & {$[0.666]$} & {$[0.795]$} \\
\hline Earnings-to-Price & -0.247 & -0.229 & -0.204 & 0.029 & 0.043 & 0.054 & -0.140 & -0.264 & 0.002 \\
& {$[-0.095]$} & {$[0.011]$} & {$[0.022]$} & {$[0.043]$} & {$[0.068]$} & {$[0.084]$} & {$[0.059]$} & {$[0.085]$} & {$[0.100]$} \\
\hline Market capitalization & 179 & 252 & 228 & 928 & 609 & 792 & 1,673 & 887 \\
(\$ million) & {$[35]$} & {$[33]$} & {$[25]$} & {$[57]$} & {$[82]$} & {$[76]$} & {$[49]$} & {$[71]$} & {$[60]$} \\
\hline
\end{tabular}

Notes:

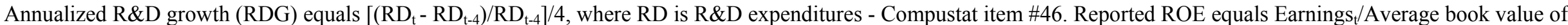

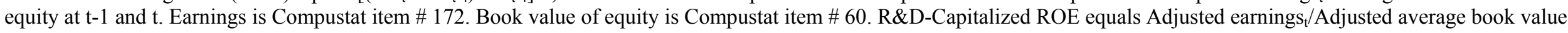

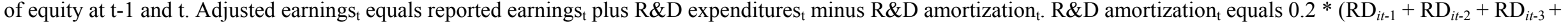

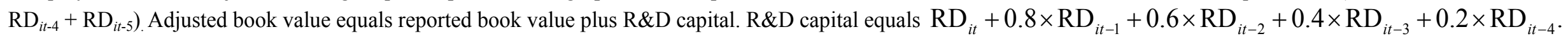
Book-to-market, earnings-to-price, and market capitalization are computed as of the fiscal year-end. R\&D-to-sales equals Compustat item \#46 divided by item \# 12 . 


\section{Table 4}

\section{Earnings change (momentum) biases: Reported versus R\&D-Capitalized momentum values}

Mean and median values of various variables for portfolios ranked by R\&D growth minus earnings momentum and R\&D-to-sales. Median values are in square brackets. Numbers in parentheses are t-statistics. The sample consists of 17,865 firm-year observations evenly allocated to the nine portfolios.

\begin{tabular}{|c|c|c|c|c|c|c|c|c|c|}
\hline R\&D growth minus earnings & \multicolumn{3}{|c|}{ High } & \multicolumn{3}{|c|}{ Medium } & \multicolumn{3}{|c|}{ Low } \\
\hline R\&D-to-Sales (RDS) & High & Medium & Low & High & Medium & Low & High & Medium & Low \\
\hline R\&D Growth [RDG(5)] & $\begin{array}{c}2.771 \\
{[1.216]}\end{array}$ & $\begin{array}{c}2.050 \\
{[0.995]}\end{array}$ & $\begin{array}{c}1.549 \\
{[0.728]}\end{array}$ & $\begin{array}{c}0.691 \\
{[0.536]}\end{array}$ & $\begin{array}{c}0.519 \\
{[0.438]}\end{array}$ & $\begin{array}{c}0.361 \\
{[0.321]}\end{array}$ & $\begin{array}{c}0.710 \\
{[0.358]}\end{array}$ & $\begin{array}{c}0.504 \\
{[0.251]}\end{array}$ & $\begin{array}{c}0.116 \\
{[0.042]}\end{array}$ \\
\hline $\begin{array}{l}\text { R\&D growth minus earnings } \\
\text { momentum }\end{array}$ & $\begin{array}{l}10.563 \\
{[3.148]}\end{array}$ & $\begin{array}{c}6.116 \\
{[2.182]}\end{array}$ & $\begin{array}{c}5.362 \\
{[1.940]}\end{array}$ & $\begin{array}{c}0.294 \\
{[0.288]}\end{array}$ & $\begin{array}{c}0.282 \\
{[0.281]}\end{array}$ & $\begin{array}{c}0.254 \\
{[0.227]}\end{array}$ & $\begin{array}{c}-6.346 \\
{[-1.520]}\end{array}$ & $\begin{array}{c}-6.833 \\
{[-1.526]}\end{array}$ & $\begin{array}{c}-6.739 \\
{[-1.458]}\end{array}$ \\
\hline R\&D-to-sales (RDS) & $\begin{array}{c}2.877 \\
{[0.135]}\end{array}$ & $\begin{array}{c}0.047 \\
{[0.045]}\end{array}$ & $\begin{array}{c}0.011 \\
{[0.011]}\end{array}$ & $\begin{array}{c}0.302 \\
{[0.075]}\end{array}$ & $\begin{array}{c}0.027 \\
{[0.026]}\end{array}$ & $\begin{array}{c}0.008 \\
{[0.008]}\end{array}$ & $\begin{array}{c}0.259 \\
{[0.080]}\end{array}$ & $\begin{array}{c}0.027 \\
{[0.025]}\end{array}$ & $\begin{array}{c}0.007 \\
{[0.007]}\end{array}$ \\
\hline $\begin{array}{l}\text { Reported earnings } \\
\text { momentum }[\operatorname{EM}(5)]\end{array}$ & $\begin{array}{l}-7.792 \\
{[-1.580]}\end{array}$ & $\begin{array}{l}-4.066 \\
{[-0.942]}\end{array}$ & $\begin{array}{c}-3.813 \\
{[-0.978]}\end{array}$ & $\begin{array}{c}0.397 \\
{[0.266]}\end{array}$ & $\begin{array}{c}0.237 \\
{[0.198]}\end{array}$ & $\begin{array}{c}0.107 \\
{[0.094]}\end{array}$ & $\begin{array}{c}7.055 \\
{[1.910]}\end{array}$ & $\begin{array}{c}7.337 \\
{[1.827]}\end{array}$ & $\begin{array}{c}6.856 \\
{[1.486]}\end{array}$ \\
\hline $\begin{array}{l}\text { R\&D-capitalized earnings } \\
\text { momentum }\left[\operatorname{EM}(5)^{\mathrm{C}}\right]\end{array}$ & $\begin{array}{l}-6.434 \\
{[-0.986]}\end{array}$ & $\begin{array}{l}-3.029 \\
{[-0.719]}\end{array}$ & $\begin{array}{c}-3.529 \\
{[-0.898]}\end{array}$ & $\begin{array}{c}0.832 \\
{[0.249]}\end{array}$ & $\begin{array}{c}0.281 \\
{[0.187]}\end{array}$ & $\begin{array}{c}0.057 \\
{[0.089]}\end{array}$ & $\begin{array}{c}6.369 \\
{[1.439]}\end{array}$ & $\begin{array}{c}6.872 \\
{[1.560]}\end{array}$ & $\begin{array}{c}5.962 \\
{[1.353]}\end{array}$ \\
\hline $\begin{array}{l}\text { Reported earnings } \\
\text { momentum minus R\&D- } \\
\text { capitalized earnings } \\
\left.\text { momentum[EM }(5)-\operatorname{EM}(5)^{\mathrm{C}}\right]\end{array}$ & $\begin{array}{l}-1.357 \\
(-0.751) \\
{[-0.654]} \\
(-0.362)\end{array}$ & $\begin{array}{l}-1.037 \\
(-0.909) \\
{[-0.299]} \\
(-0.262)\end{array}$ & $\begin{array}{l}-0.284 \\
(-0.612) \\
{[-0.079]} \\
(-0.170)\end{array}$ & $\begin{array}{r}-0.435 \\
(-1.868) \\
{[0.034]} \\
(0.146) \\
\end{array}$ & $\begin{array}{c}-0.044 \\
(-0.877) \\
{[0.015]} \\
(0.301)\end{array}$ & $\begin{array}{l}0.050 \\
(3.253) \\
{[0.009]} \\
(0.585)\end{array}$ & $\begin{array}{l}0.686 \\
(0.519) \\
{[0.373]} \\
(0.283) \\
\end{array}$ & $\begin{array}{l}0.465 \\
(0.287) \\
{[0.204]} \\
(0.126) \\
\end{array}$ & $\begin{array}{l}0.894 \\
(1.002) \\
{[0.080]} \\
(0.246)\end{array}$ \\
\hline Book-to-market & $\begin{array}{c}0.553 \\
{[0.492]}\end{array}$ & $\begin{array}{l}-0.051 \\
{[0.684]}\end{array}$ & $\begin{array}{c}0.136 \\
{[0.874]}\end{array}$ & $\begin{array}{c}0.537 \\
{[0.476]}\end{array}$ & $\begin{array}{c}0.399 \\
{[0.660]}\end{array}$ & $\begin{array}{c}0.534 \\
{[0.769]}\end{array}$ & $\begin{array}{c}0.409 \\
{[0.414]}\end{array}$ & $\begin{array}{c}0.503 \\
{[0.550]}\end{array}$ & $\begin{array}{c}0.503 \\
{[0.693]}\end{array}$ \\
\hline Earnings-to-price & $\begin{array}{l}-0.269 \\
{[-0.054]}\end{array}$ & $\begin{array}{l}-0.424 \\
{[0.001]}\end{array}$ & $\begin{array}{c}-0.607 \\
{[-0.002]}\end{array}$ & $\begin{array}{l}-0.015 \\
{[0.054]}\end{array}$ & $\begin{array}{c}0.050 \\
{[0.072]}\end{array}$ & $\begin{array}{c}0.028 \\
{[0.079]}\end{array}$ & $\begin{array}{l}-0.018 \\
{[0.050]}\end{array}$ & $\begin{array}{c}0.055 \\
{[0.076]}\end{array}$ & $\begin{array}{c}0.060 \\
{[0.094]}\end{array}$ \\
\hline $\begin{array}{l}\text { Market capitalization } \\
(\$ \text { million })\end{array}$ & $\begin{array}{l}327 \\
{[45]}\end{array}$ & $\begin{array}{l}601 \\
{[45]}\end{array}$ & $\begin{array}{l}488 \\
{[46]}\end{array}$ & $\begin{array}{r}2,456 \\
{[127]}\end{array}$ & $\begin{array}{l}1,315 \\
{[244]}\end{array}$ & $\begin{array}{l}1,747 \\
{[207]}\end{array}$ & $\begin{array}{r}1,092 \\
{[59]}\end{array}$ & $\begin{array}{r}1,117 \\
{[81]}\end{array}$ & $\begin{array}{r}1,084 \\
{[84]}\end{array}$ \\
\hline
\end{tabular}

Notes:

$\mathrm{R} \& \mathrm{D}$ growth equals $\left[\left(\mathrm{RD}_{\mathrm{t}}-\mathrm{RD}_{\mathrm{t}-4}\right) / \mathrm{RD}_{\mathrm{t}-4}\right]$, where $\mathrm{RD}$ is $\mathrm{R} \& \mathrm{D}$ expenditures - Compustat item \#46. Reported earnings momentum equals (earnings $s_{t}-$ earnings $\left.s_{\mathrm{t}-4}\right) /\left(\right.$ earnings $_{\mathrm{t}-4} \mid$, where earnings $s_{t}$ is Compustat item \# 172. R\&D-capitalized earnings momentum equals (adjusted earnings $s_{t}-$ adjusted earnings $\left.s_{t-4}\right) / \mid$ adjusted earnings $\mathrm{s}_{\mathrm{t}-4} \mid$. Adjusted earnings $\mathrm{s}_{\mathrm{t}}$ equals reported

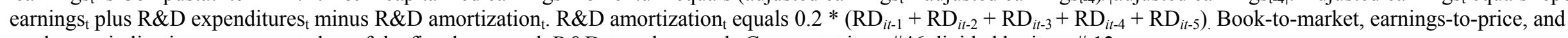
market capitalization are computed as of the fiscal year-end. R\&D-to-sales equals Compustat item \#46 divided by item \# 12. 


\section{Table 5}

\section{The Consequences of ROE Biases}

Mean coefficient estimates of cross-sectional regressions of monthly stock returns on lagged values of fundamental variables. The returns are for the seven years following a given fiscal year over the period 1975-1995. The returns for year 1 are the 12 monthly returns of firm i from the $7^{\text {th }}$ month after fiscal year-end, for year 2 are the 12 monthly returns of firm i from the $19^{\text {th }}$ month after fiscal year-end, and so on for year 7 . The mean coefficients for each year ahead are computed over 252 monthly regressions in the period 1975-1995 (21 years times 12 months per year). T-statistics are reported in parentheses.

\begin{tabular}{|c|c|c|c|c|c|c|c|c|c|c|c|}
\hline \multicolumn{12}{|c|}{$\begin{array}{l}\text { Panel A: Benchmark Regression } \\
\mathrm{R}_{\mathrm{i}, \mathrm{t}+\mathrm{j}}=\mathrm{c}_{0, \mathrm{j}}+\mathrm{c}_{1, \mathrm{j}} \beta_{\mathrm{i}, \mathrm{t}}+\mathrm{c}_{2, \mathrm{j}} \ln (\mathrm{M})_{\mathrm{i}, \mathrm{t}}+\mathrm{c}_{3,}\end{array}$} \\
\hline $\begin{array}{l}\text { Years ahead } \\
\text { Regressions }\end{array}$ & Intercept & Beta & $\begin{array}{c}\text { Size } \\
M\end{array}$ & $\mathrm{~B} / \mathrm{M}$ & $\mathrm{A} / \mathrm{B}$ & $\mathrm{E}(+) / \mathrm{M}$ & $\begin{array}{c}\mathrm{E} / \mathrm{M} \\
\text { Dummy }\end{array}$ & $\mathrm{RDC} / \mathrm{M}$ & $\begin{array}{l}\text { ROE bias } \\
\text { score }\end{array}$ & $\begin{array}{l}\text { Change in } \\
\text { ROE bias } \\
\text { sccore }\end{array}$ & Adj. $\mathrm{R}^{2}$ \\
\hline \multirow[t]{2}{*}{ Year 1} & 0.0303 & 0.0000 & -0.0014 & 0.0024 & 0.0001 & 0.0027 & -0.0043 & 0.0027 & - & - & 0.019 \\
\hline & $(13.320)$ & $(0.030)$ & $(-3.738)$ & $(3.190)$ & $(0.120)$ & $(0.327)$ & $(-3.172)$ & $(6.822)$ & & & \\
\hline \multirow[t]{2}{*}{ Year 3} & 0.0211 & 0.0004 & -0.0005 & 0.0016 & -0.0003 & 0.0083 & -0.0014 & 0.0015 & - & - & 0.01 \\
\hline & $(8.508)$ & $(0.443)$ & $(-1.299)$ & $(1.737)$ & $(-0.310)$ & $(0.918)$ & $(-0.935)$ & $(3.480)$ & & & \\
\hline \multirow[t]{2}{*}{ Year 5} & 0.0206 & 0.0007 & -0.0001 & 0.0001 & -0.0024 & 0.0065 & 0.0008 & 0.0021 & - & - & 0.005 \\
\hline & $(7.021)$ & $(0.767)$ & $(-0.347)$ & $(0.083)$ & $(-1.898)$ & $(0.494)$ & $(0.434)$ & $(3.291)$ & & & \\
\hline \multirow[t]{2}{*}{ Year 7} & 0.018 & 0.0007 & 0.0002 & 0.0008 & -0.0032 & 0.0027 & -0.0008 & 0.0016 & - & - & 0.004 \\
\hline & $(5.667)$ & $(0.741)$ & $(0.444)$ & $(0.738)$ & $(-2.468)$ & $(0.233)$ & $(-0.409)$ & $(2.653)$ & & & \\
\hline \multicolumn{12}{|c|}{ Panel B: Benchmark regression and the ROE bias score variable } \\
\hline \multirow[t]{2}{*}{ Year 1} & 0.0319 & 0.0003 & -0.0014 & 0.0022 & -0.0000 & -0.0008 & -0.0037 & 0.0028 & -0.0031 & - & 0.02 \\
\hline & $(13.799)$ & $(0.292)$ & $(-3.824)$ & $(2.936)$ & $(-0.012)$ & $(-0.100)$ & $(-2.734)$ & $(7.129)$ & $(-2.602)$ & & \\
\hline \multirow[t]{2}{*}{ Year 3} & 0.0212 & 0.0004 & -0.0005 & 0.0015 & -0.0004 & 0.0069 & -0.0013 & 0.0015 & -0.0003 & - & 0.01 \\
\hline & $(8.145)$ & $(0.471)$ & $(-1.320)$ & (1.664) & $(-0.388)$ & $(0.753)$ & $(-0.845)$ & $(3.438)$ & $(-0.211)$ & & \\
\hline \multirow[t]{2}{*}{ Year 5} & 0.0197 & 0.0007 & -0.0001 & 0.0001 & -0.0023 & 0.0083 & 0.0003 & 0.0021 & 0.0016 & - & 0.005 \\
\hline & $(6.646)$ & $(0.736)$ & $(-0.278)$ & $(0.145)$ & $(-1.829)$ & $(0.611)$ & $(0.174)$ & $(3.237)$ & $(0.953)$ & & \\
\hline \multirow[t]{2}{*}{ Year 7} & 0.0172 & 0.0005 & 0.0002 & 0.001 & -0.0032 & 0.0066 & -0.0010 & 0.0015 & 0.0017 & - & 0.004 \\
\hline & $(5.294)$ & $(0.532)$ & $(0.475)$ & $(0.909)$ & $(-2.456)$ & $(0.583)$ & $(-0.503)$ & $(2.532)$ & $(0.934)$ & & \\
\hline \multicolumn{12}{|c|}{ 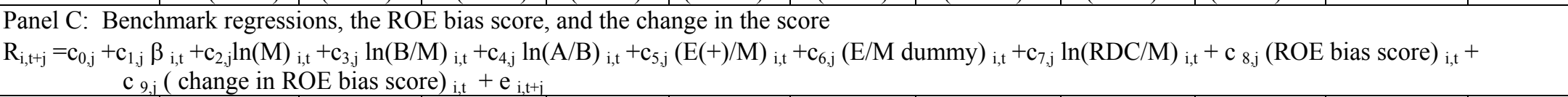 } \\
\hline \multirow[t]{2}{*}{ Year 1} & 0.0317 & 0.0002 & -0.0014 & 0.0023 & -0.0000 & -0.0005 & -0.0036 & 0.0028 & -0.0027 & 0.0009 & 0.02 \\
\hline & $(13.648)$ & $(0.286)$ & $(-3.817)$ & $(2.999)$ & $(-0.022)$ & $(-0.050)$ & $(-2.627)$ & $(6.957)$ & $(-2.111)$ & $(0.570)$ & \\
\hline \multirow[t]{2}{*}{ Year 2} & 0.0278 & -0.0011 & -0.0010 & 0.0015 & 0.0009 & -0.0071 & -0.0016 & 0.0018 & -0.0009 & 0.0002 & 0.015 \\
\hline & $(10.510)$ & $(-1.241)$ & $(-2.769)$ & $(1.905)$ & $(0.950)$ & $(-0.746)$ & $(-1.038)$ & $(4.360)$ & $(-0.612)$ & $(0.157)$ & \\
\hline
\end{tabular}


Table 5: continued

Panel D: Benchmark regression and the ROE bias score controlling also for $\left\{\mathrm{RDG}_{\mathrm{it}} /\left[\left(\mathrm{RDG}_{\mathrm{it}} / 2\right)+1\right]\right\}-\mathrm{ROE}_{\mathrm{it}}$ reversals

$\mathrm{R}_{\mathrm{i}, \mathrm{t}+\mathrm{j}}=\mathrm{c}_{0, \mathrm{j}}+\mathrm{c}_{1, \mathrm{j}} \beta_{\mathrm{i}, \mathrm{t}}+\mathrm{c}_{2, \mathrm{j}} \ln (\mathrm{M})_{\mathrm{i}, \mathrm{t}}+\mathrm{c}_{3, \mathrm{j}} \ln (\mathrm{B} / \mathrm{M})_{\mathrm{i}, \mathrm{t}}+\mathrm{c}_{4, \mathrm{j}} \ln (\mathrm{A} / \mathrm{B})_{\mathrm{i}, \mathrm{t}}+\mathrm{c}_{5, \mathrm{j}}\left(\mathrm{E}(+\mathrm{)} / \mathrm{M})_{\mathrm{i}, \mathrm{t}}+\mathrm{c}_{6, \mathrm{j}}(\mathrm{E} / \mathrm{M} \text { dummy })_{\mathrm{i}, \mathrm{t}}+\mathrm{c}_{7, \mathrm{j}} \ln (\mathrm{RDC} / \mathrm{M})_{\mathrm{i}, \mathrm{t}}+\mathrm{c}_{8, \mathrm{j}}(\mathrm{ROE} \text { bias score })_{\mathrm{i}, \mathrm{t}}+\right.$ $\mathrm{c}_{9, \mathrm{j}}\left(\text { ROE bias score* } \mathrm{D}_{\mathrm{pn}}\right)_{\mathrm{i}, \mathrm{t}}+\mathrm{c}_{10, \mathrm{j}}\left(\mathrm{ROE} \text { bias score* } \mathrm{D}_{\mathrm{np}}\right)_{\mathrm{i}, \mathrm{t}} \mathrm{e}_{\mathrm{i}, \mathrm{t}+\mathrm{i}}$

\begin{tabular}{|c|c|c|c|c|c|c|c|c|c|c|c|c|}
\hline Regressions & Intercept & $\begin{array}{c}\text { Beta } \\
\beta\end{array}$ & $\begin{array}{c}\text { Size } \\
M\end{array}$ & $\mathrm{BM}$ & $\mathrm{AB}$ & $\mathrm{E}(+) / \mathrm{M}$ & $\begin{array}{c}\mathrm{E} / \mathrm{M} \\
\text { Dummy }\end{array}$ & $\mathrm{RCM}$ & $\begin{array}{l}\text { ROE } \\
\text { bias } \\
\text { score }\end{array}$ & $\begin{array}{l}\text { ROE bias } \\
\text { Score* } D_{p n}\end{array}$ & $\begin{array}{l}\text { ROE bias } \\
\text { Score* } D_{n p}\end{array}$ & Adj. $R^{2}$ \\
\hline \multirow[t]{2}{*}{ Year 1} & 0.0319 & 0.0003 & -0.0014 & 0.0023 & -0.0000 & -0.0009 & -0.0037 & 0.0028 & -0.0028 & 0.0018 & -0.0005 & 0.02 \\
\hline & $(13.584)$ & $(0.305)$ & $(-3.816)$ & $(3.008)$ & $(-0.040)$ & $(-0.105)$ & $(-2.709)$ & $(7.086)$ & $(-2.361)$ & $(0.478)$ & $(-0.273)$ & \\
\hline \multirow[t]{2}{*}{ Year 2} & 0.0278 & -0.0011 & -0.0010 & 0.0015 & 0.0010 & -0.008 & -0.0017 & 0.0017 & -0.0007 & 0.0026 & -0.0005 & 0.015 \\
\hline & $(10.536)$ & $(-1.205)$ & $(-2.783)$ & $(1.931)$ & $(0.999)$ & $(-0.832)$ & $(-1.082)$ & $(4.310)$ & $(-0.537)$ & $(0.625)$ & $(-0.283)$ & \\
\hline
\end{tabular}

Panel E: Benchmark regression and the ROE bias score for positive to negative reversals only

$\mathrm{R}_{\mathrm{i}, \mathrm{t}+\mathrm{i}}=\mathrm{c}_{0, \mathrm{j}}+\mathrm{c}_{1, \mathrm{j}} \beta_{\mathrm{i}, \mathrm{t}}+\mathrm{c}_{2, \mathrm{j}} \ln (\mathrm{M})_{\mathrm{i}, \mathrm{t}}+\mathrm{c}_{3, \mathrm{j}} \ln (\mathrm{B} / \mathrm{M})_{\mathrm{i}, \mathrm{t}}+\mathrm{c}_{4, \mathrm{j}} \ln (\mathrm{A} / \mathrm{B})_{\mathrm{i}, \mathrm{t}}+\mathrm{c}_{5, \mathrm{j}}(\mathrm{E}(+) / \mathrm{M})_{\mathrm{i}, \mathrm{t}}+\mathrm{c}_{6, \mathrm{j}}(\mathrm{E} / \mathrm{M} \text { dummy })_{\mathrm{i}, \mathrm{t}}+\mathrm{c}_{7, \mathrm{j}} \ln (\mathrm{RDC} / \mathrm{M})_{\mathrm{i}, \mathrm{t}}+\mathrm{c}_{8, \mathrm{j}}(\mathrm{ROE} \text { bias score })_{\mathrm{i}, \mathrm{t}}+\mathrm{e}_{\mathrm{i}, \mathrm{t}+\mathrm{i}}$

\begin{tabular}{|c|c|c|c|c|c|c|c|c|c|c|c|c|}
\hline Year 1 & 0.0342 & -0.001 & -0.0022 & 0.0013 & 0.0002 & 0.007 & -0.0037 & 0.0028 & 0.0065 & - & - & 0.008 \\
\hline & $(6.200)$ & $(-0.510)$ & $(-3.264)$ & $(0.668)$ & $(0.066)$ & $(0.339)$ & $(-0.524)$ & $(3.004)$ & $(0.691)$ & & & \\
\hline Year 2 & 0.029 & -0.0018 & -0.0015 & 0.0009 & 0.0034 & -0.0092 & -0.0018 & 0.0031 & 0.0116 & - & - & 0.006 \\
\hline & $(5.049)$ & $(-0.818)$ & $(-2.488)$ & $(0.404)$ & (1.499) & $(-0.425)$ & $(-0.323)$ & $(3.095)$ & $(1.485)$ & & & \\
\hline
\end{tabular}

Panel F: Benchmark regression and the ROE bias score for negative to positive reversals only

$\mathrm{R}_{\mathrm{i}, \mathrm{t}+\mathrm{i}}=\mathrm{c}_{0, \mathrm{j}}+\mathrm{c}_{1, \mathrm{j}} \beta_{\mathrm{i}, \mathrm{t}}+\mathrm{c}_{2, \mathrm{j}} \ln (\mathrm{M})_{\mathrm{i}, \mathrm{t}}+\mathrm{c}_{3, \mathrm{j}} \ln (\mathrm{B} / \mathrm{M})_{\mathrm{i}, \mathrm{t}}+\mathrm{c}_{4, \mathrm{j}} \ln (\mathrm{A} / \mathrm{B})_{\mathrm{i}, \mathrm{t}}+\mathrm{c}_{5, \mathrm{j}}(\mathrm{E}(+) / \mathrm{M})_{\mathrm{i}, \mathrm{t}}+\mathrm{c}_{6, \mathrm{j}}(\mathrm{E} / \mathrm{M} \text { dummy })_{\mathrm{i}, \mathrm{t}}+\mathrm{c}_{7, \mathrm{j}} \ln (\mathrm{RDC} / \mathrm{M})_{\mathrm{i}, \mathrm{t}}+\mathrm{c}_{8, \mathrm{j}}(\mathrm{ROE} \text { bias score })_{\mathrm{i}, \mathrm{t}}+\mathrm{e}_{\mathrm{i}, \mathrm{t}+\mathrm{i}}$

\begin{tabular}{|l|c|r|r|r|r|r|r|r|r|r|r|r|r|}
\hline Year 1 & 0.019 & -0.0008 & -0.0009 & 0.001 & -0.0034 & 0.0433 & 0.002 & 0.0027 & 0.0139 & - & - & 0.005 & \\
\hline & $(3.317)$ & $(-0.371)$ & $(-1.462)$ & $(0.546)$ & $(-1.162)$ & $(1.831)$ & $(0.731)$ & $(3.065)$ & $(2.011)$ & & \\
\hline Year 2 & 0.0258 & -0.0032 & -0.0007 & 0.0025 & 0.0027 & -0.0028 & 0.001 & 0.0014 & -0.0013 & - & - \\
\hline & $(3.619)$ & $(-1.198)$ & $(-1.169)$ & $(1.345)$ & $(0.987)$ & $(-0.104)$ & $(0.197)$ & $(1.280)$ & $(-0.169)$ & & \\
\hline
\end{tabular}

Notes:

$\mathrm{R}_{\mathrm{i}, \mathrm{t}+\mathrm{j}}=$ monthly stock returns of firm $\mathrm{i}$, stating with the $7^{\text {th }}$ month after fiscal t year-end, $\mathrm{j}=1, \ldots . ., 84, \beta_{\mathrm{i}, \mathrm{t}}=$ CAPM-based beta of firm $\mathrm{i}$, estimated from 60 monthly stock returns up to month $\mathrm{t}$ (one month preceding the return calculation); a minimum of 24 months is required, $\mathrm{M}_{\mathrm{i}, \mathrm{t}}=$ market value of firm $\mathrm{i}$, calculated as price times number of shares outstanding at $\mathrm{t}$, the beginning of the returns calculation period, $(\mathrm{B} / \mathrm{M})_{\mathrm{i}, \mathrm{t}}=$ book-to-market ratio of firm $\mathrm{i}$ at fiscal year-end, $(\mathrm{A} / \mathrm{B})_{\mathrm{i}, \mathrm{t}}=$ ratio of book value of total assets to book value of common equity of firm $\mathrm{i}$ at fiscal year-end, $[\mathrm{E}(+) / \mathrm{M}]_{\mathrm{i}, \mathrm{t}}=$ ratio of positive earnings to the market value of equity of firm $\mathrm{i}$ at fiscal year-end and equal to 0 when earnings are negative, $(\mathrm{E} / \mathrm{M}$ dummy $)_{\mathrm{i}, \mathrm{t}}=1$ if earnings are negative and 0 otherwise, $(\mathrm{RDC} / \mathrm{M})_{\mathrm{i}, \mathrm{t}}=$ estimated $\mathrm{R} \& \mathrm{D}$ capital-to-market value of equity at fiscal year-end, $(\mathrm{ROE} \text { bias score })_{\mathrm{i}, \mathrm{t}}=$ scaled decile rank of $\left(\left\{\mathrm{RDG}_{\mathrm{it}} /\left[\left(\mathrm{RDG}_{\mathrm{it}} / 2\right)+1\right]\right\}-\mathrm{ROE}_{\mathrm{it}}\right)$ constructed by ranking the values of this difference into deciles $(0,9)$ each year $\mathrm{t}$ and dividing the decile number by nine so that each firm $\mathrm{i}$ takes on a decile rank value ranging between zero and one in each year $t$. The ranking is on an ascending order and thus firms with the most negative $\left\{\mathrm{RDG}_{\mathrm{it}} /\left[\left(\mathrm{RDG}_{\mathrm{it}} / 2\right)+1\right]\right\}-$ $R O E_{i t}$ values are assigned the score of zero while the firms with the most positive $\left\{\mathrm{RDG}_{\mathrm{it}} /\left[\left(\mathrm{RDG}_{\mathrm{it}} / 2\right)+1\right]\right\}-\mathrm{ROE}_{\mathrm{it}}$ values are assigned the score of 1 . $\mathrm{D}_{\mathrm{pn}}=1$ when

$\left\{\mathrm{RDG}_{\mathrm{it}} /\left[\left(\mathrm{RDG}_{\mathrm{it}} / 2\right)+1\right]\right\}-\mathrm{ROE}_{\mathrm{it}}$ is positive at $\mathrm{t}-1$ but reverses to negative at $\mathrm{t}, \mathrm{D}_{\mathrm{np}}=1$ when $\left\{\mathrm{RDG}_{\mathrm{it}} /\left[\left(\mathrm{RDG}_{\mathrm{it}} / 2\right)+1\right]\right\}-\mathrm{ROE}_{\mathrm{it}}$ is negative at $\mathrm{t}-1$ but reverses to positive at $\mathrm{t}$. 


\section{Table 6}

\section{ROE Bias Reversal Analysis}

In each year from 1975 to 1995 we detect firms for which the difference RDG/[(RDG/2)+1]\}-ROE reverses. For example, for year 1980 we detect firms that had RDG/[(RDG/2)+1]\}-ROE $>0$ in 1979 but $<0$ in 1980. This is our "positive to negative reversal" portfolio. We also detect firms that had RDG/[(RDG/2)+1] $\}-\mathrm{ROE}<0$ in 1979 but $>0$ in 1980. This is our "negative to positive reversal" portfolio. The remaining firms comprise the "Non reversal" portfolio. We trace these firms five years before and one year after the reversal year. For each of these seven years and for each portfolio we report mean values of key characteristics including annual raw and abnormal returns. These returns are for the year following the disclosure of the financial statements, i.e. we start the annual return calculation from the seventh month after fiscal year end. The abnormal returns are the residuals from the regression:

$\mathrm{R}_{\mathrm{i}, \mathrm{t}+\mathrm{j}}=\mathrm{c}_{0, \mathrm{j}}+\mathrm{c}_{1, \mathrm{j}} \beta_{\mathrm{i}, \mathrm{t}}+\mathrm{c}_{2, \mathrm{j}} \ln (\mathrm{M})_{\mathrm{i}, \mathrm{t}}+\mathrm{c}_{3, \mathrm{j}} \ln (\mathrm{B} / \mathrm{M})_{\mathrm{i}, \mathrm{t}}+\mathrm{c}_{4, \mathrm{j}} \ln (\mathrm{A} / \mathrm{B})_{\mathrm{i}, \mathrm{t}}+\mathrm{c}_{5, \mathrm{j}}(\mathrm{E}(+) / \mathrm{M})_{\mathrm{i}, \mathrm{t}}+\mathrm{c}_{6, \mathrm{j}}(\mathrm{E} / \mathrm{M} \text { dummy })_{\mathrm{i}, \mathrm{t}}+\mathrm{c}_{7, \mathrm{j}} \ln (\mathrm{RDC} / \mathrm{M})_{\mathrm{i}, \mathrm{t}}+\mathrm{e}_{\mathrm{i}, \mathrm{t}+\mathrm{j}}$ We run this regression each year for all firms and we report the mean residuals for the firms that belong to each portfolio.

\section{Panel A: "positive to negative reversal" portfolio}

\begin{tabular}{|c|c|c|c|c|c|c|c|}
\hline & & & relative & eversal & & & \\
\hline & $t-5$ & $t-4$ & $t-3$ & $t-2$ & $t-1$ & t & $t+1$ \\
\hline R\&D growth - ROE & 0.117 & 0.191 & 0.210 & 0.186 & 0.277 & -0.118 & -0.024 \\
\hline Raw returns & 0.100 & 0.099 & 0.094 & 0.240 & 0.352 & 0.214 & 0.200 \\
\hline Abnormal returns & -0.094 & -0.106 & -0.128 & 0.028 & 0.133 & 0.020 & -0.007 \\
\hline R\&D growth Rate & 0.221 & 0.261 & 0.242 & 0.204 & 0.155 & 0.018 & 0.049 \\
\hline Reported $\mathrm{ROE}$ & 0.103 & 0.070 & 0.032 & 0.018 & -0.122 & 0.136 & 0.073 \\
\hline R\&D-Capitalized ROE & 0.119 & 0.111 & 0.073 & 0.050 & -0.015 & 0.098 & 0.067 \\
\hline R\&D to sales & 0.048 & 0.065 & 0.076 & 0.062 & 0.059 & 0.047 & 0.053 \\
\hline Earnings-to-price & 0.091 & 0.084 & 0.072 & 0.062 & 0.044 & 0.077 & 0.064 \\
\hline Book-to-market & 0.896 & 0.896 & 0.921 & 0.936 & 0.868 & 0.807 & 0.774 \\
\hline Beta & 1.291 & 1.252 & 1.240 & 1.218 & 1.189 & 1.163 & 1.144 \\
\hline Market Capitalization & 843 & 824 & 794 & 794 & 850 & 958 & 1126 \\
\hline No. of firms & 101 & 111 & 122 & 130 & 139 & 140 & 128 \\
\hline
\end{tabular}


Table 6: continued

Panel B: "negative to positive reversal" portfolio

\begin{tabular}{|c|c|c|c|c|c|c|c|}
\hline & & & relative & reversal & & & \\
\hline & $t-5$ & $t-4$ & $t-3$ & $t-2$ & $t-1$ & t & $t+1$ \\
\hline R\&D growth - ROE & 0.152 & 0.095 & 0.074 & 0.015 & -0.281 & 0.201 & 0.170 \\
\hline Raw returns & 0.203 & 0.252 & 0.319 & 0.192 & 0.105 & 0.144 & 0.195 \\
\hline Abnormal returns & -0.008 & 0.023 & 0.098 & -0.010 & -0.080 & -0.025 & 0.000 \\
\hline R\&D growth Rate & 0.211 & 0.134 & 0.111 & 0.076 & 0.044 & 0.186 & 0.196 \\
\hline Reported ROE & 0.059 & 0.039 & 0.036 & 0.061 & 0.325 & -0.015 & 0.026 \\
\hline R\&D-Capitalized ROE & 0.091 & 0.068 & 0.067 & 0.081 & 0.121 & 0.027 & 0.052 \\
\hline R\&D to sales & 0.058 & 0.062 & 0.055 & 0.043 & 0.045 & 0.057 & 0.065 \\
\hline Earnings-to-price & 0.082 & 0.078 & 0.077 & 0.078 & 0.083 & 0.048 & 0.055 \\
\hline Book-to-market & 0.958 & 0.938 & 0.895 & 0.833 & 0.779 & 0.806 & 0.803 \\
\hline Beta & 1.254 & 1.233 & 1.222 & 1.204 & 1.209 & 1.180 & 1.156 \\
\hline Market Capitalization & 671 & 673 & 734 & 751 & 697 & 760 & 890 \\
\hline No. of firms & 91 & 101 & 107 & 116 & 132 & 132 & 120 \\
\hline
\end{tabular}


Table 6: continued

Panel C: "Non reversal" portfolio

\begin{tabular}{|c|c|c|c|c|c|c|c|}
\hline & & & relative & reversal & & & \\
\hline & $t-5$ & $t-4$ & $t-3$ & $t-2$ & $t-1$ & $t$ & $t+1$ \\
\hline R\&D growth - ROE & 0.130 & 0.145 & 0.141 & 0.166 & 0.231 & 0.250 & 0.202 \\
\hline Raw returns & 0.214 & 0.222 & 0.213 & 0.185 & 0.180 & 0.170 & 0.189 \\
\hline Abnormal returns & 0.018 & 0.015 & 0.008 & -0.005 & -0.007 & 0.001 & 0.000 \\
\hline R\&D growth rate & 0.216 & 0.225 & 0.234 & 0.245 & 0.256 & 0.240 & 0.211 \\
\hline Reported ROE & 0.086 & 0.081 & 0.093 & 0.079 & 0.025 & -0.010 & 0.009 \\
\hline R\&D-Capitalized ROE & 0.113 & 0.109 & 0.103 & 0.093 & 0.078 & 0.056 & 0.060 \\
\hline$R \& D$ to sales & 0.079 & 0.094 & 0.250 & 0.362 & 0.704 & 0.681 & 0.657 \\
\hline Earnings-to-price & 0.085 & 0.080 & 0.075 & 0.068 & 0.061 & 0.056 & 0.054 \\
\hline Book-to-market & 0.830 & 0.800 & 0.778 & 0.756 & 0.736 & 0.735 & 0.722 \\
\hline Beta & 1.263 & 1.259 & 1.257 & 1.256 & 1.254 & 1.229 & 1.201 \\
\hline Market Capitalization & 938 & 957 & 979 & 998 & 1001 & 1101 & 1328 \\
\hline No. of firms & 572 & 632 & 697 & 775 & 868 & 870 & 796 \\
\hline
\end{tabular}


Table 7

\section{The Consequences of Earnings Momentum Biases}

Mean coefficient estimates of cross-sectional regressions of monthly stock returns on lagged values of fundamental variables. The returns are for the seven years following a given fiscal year over the period 1975-1995. The returns for year 1 are the 12 monthly returns of firm i from the $7^{\text {th }}$ month after fiscal year-end, for year 2 are the 12 monthly returns of firm i from the $19^{\text {th }}$ month after fiscal year-end, and so on for year 7 . The mean coefficients for each year ahead are computed over 252 monthly regressions in the period 1975-1995 (21 years times 12 months per year). T-statistics are reported in parentheses.

\begin{tabular}{|c|c|c|c|c|c|c|c|c|c|c|c|}
\hline \multicolumn{12}{|c|}{$\begin{array}{l}\text { Panel A: Benchmark Regression } \\
\mathrm{R}_{\mathrm{i}, \mathrm{t}+\mathrm{j}}=\mathrm{c}_{0, \mathrm{j}}+\mathrm{c}_{1, \mathrm{j}} \beta_{\mathrm{i}, \mathrm{t}}+\mathrm{c}_{2, \mathrm{j}} \ln (\mathrm{M})_{\mathrm{i}, \mathrm{t}}+\mathrm{c}_{3}\end{array}$} \\
\hline Regressions & Intercept & Beta & Size & $\mathrm{BM}$ & $\mathrm{AB}$ & $\mathrm{E}(+) / \mathrm{M}$ & $\begin{array}{c}\mathrm{E} / \mathrm{M} \\
\text { Dummy }\end{array}$ & $\mathrm{RDC} / \mathrm{M}$ & $\begin{array}{l}\text { EM bias } \\
\text { score }\end{array}$ & $\begin{array}{c}\text { Change in } \\
\text { EM bias } \\
\text { score }\end{array}$ & Adj. $R^{2}$ \\
\hline \multirow[t]{2}{*}{ Year 1} & 0.0262 & -0.0022 & -0.0005 & 0.0029 & -0.0004 & 0.0023 & -0.0019 & 0.0023 & - & - & 0.017 \\
\hline & $(9.846)$ & $(-1.764)$ & $(-1.269)$ & $(3.220)$ & $(-0.300)$ & $(0.223)$ & $(-1.267)$ & $(4.500)$ & & & \\
\hline \multirow[t]{2}{*}{ Year 3} & 0.0159 & -0.0003 & 0.0004 & 0.0015 & -0.0007 & 0.0151 & -0.0006 & 0.0021 & - & - & 0.01 \\
\hline & $(5.805)$ & $(-0.222)$ & $(1.159)$ & $(1.320)$ & $(-0.526)$ & $(1.427)$ & $(-0.352)$ & $(3.984)$ & & & \\
\hline \multirow[t]{2}{*}{ Year 5} & 0.0220 & 0.0000 & -0.0001 & -0.0014 & -0.0016 & 0.0106 & 0.0001 & 0.0028 & - & - & 0.004 \\
\hline & $(6.095)$ & $(0.030)$ & $(-0.231)$ & $(-1.006)$ & $(-0.919)$ & $(0.518)$ & $(0.046)$ & $(3.608)$ & & & \\
\hline \multirow[t]{2}{*}{ Year 7} & 0.0197 & $(0.0001)$ & -0.0001 & 0.0013 & -0.0011 & 0.0115 & -0.0004 & 0.0019 & - & - & 0.002 \\
\hline & $(4.987)$ & $(0.013)$ & $(-0.121)$ & $(0.586)$ & $(-0.462)$ & $(0.962)$ & $(-0.063)$ & $(2.874)$ & & & \\
\hline \multicolumn{12}{|c|}{ Panel B: Benchmark regression and the EM bias score variable } \\
\hline \multirow[t]{2}{*}{ Year 1} & 0.0277 & -0.0021 & -0.0006 & 0.0030 & -0.0003 & 0.0004 & -0.0017 & 0.0023 & -0.0020 & - & 0.017 \\
\hline & $(9.856)$ & $(-1.741)$ & $(-1.361)$ & $(3.333)$ & $(-0.263)$ & $(0.041)$ & $(-1.172)$ & $(4.607)$ & $(-1.642)$ & & \\
\hline \multirow[t]{2}{*}{ Year 3} & 0.0141 & -0.0002 & 0.0005 & 0.0013 & -0.0007 & 0.0181 & -0.0006 & 0.0020 & 0.0023 & - & 0.01 \\
\hline & $(4.936)$ & $(-0.170)$ & $(1.283)$ & $(1.196)$ & $(-0.598)$ & $(1.673)$ & $(-0.411)$ & $(3.884)$ & $(1.674)$ & & \\
\hline \multirow[t]{2}{*}{ Year 5} & 0.0212 & -0.0000 & -0.0001 & -0.0015 & -0.0016 & 0.0110 & 0.0000 & 0.0027 & 0.0012 & - & 0.004 \\
\hline & $(5.590)$ & $(-0.004)$ & $(-0.205)$ & $(-1.092)$ & $(-0.928)$ & $(0.534)$ & $(-0.020)$ & $(3.516)$ & $(0.693)$ & & \\
\hline \multirow[t]{2}{*}{ Year 7} & 0.0201 & -0.0004 & -0.0001 & 0.0011 & -0.0018 & 0.0092 & -0.0003 & 0.0017 & 0.0008 & - & 0.003 \\
\hline & $(5.025)$ & $(-0.011)$ & $(-0.198)$ & $(0.468)$ & $(-0.792)$ & $(0.528)$ & $(-0.011)$ & $(2.793)$ & $(0.762)$ & & \\
\hline \multicolumn{12}{|c|}{ 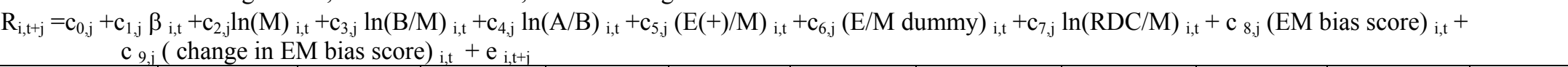 } \\
\hline \multirow[t]{2}{*}{ Year 1} & 0.0275 & -0.0021 & -0.0006 & 0.0030 & -0.0004 & 0.0003 & -0.0018 & 0.0023 & -0.0017 & 0.0004 & 0.017 \\
\hline & $(9.577)$ & $(-1.736)$ & $(-1.341)$ & $(3.317)$ & $(-0.323)$ & $(0.026)$ & $(-1.219)$ & $(4.573)$ & $(-1.108)$ & $(0.305)$ & \\
\hline \multirow[t]{2}{*}{ Year 2} & 0.0236 & -0.0006 & -0.0005 & 0.0006 & 0.0011 & 0.0089 & 0.0004 & 0.0019 & -0.0013 & 0.0006 & 0.013 \\
\hline & $(7.194)$ & $(-0.433)$ & $(-1.199)$ & $(0.556)$ & $(0.942)$ & $(0.751)$ & $(0.256)$ & $(3.838)$ & $(-0.674)$ & $(0.421)$ & \\
\hline
\end{tabular}


Table 7: continued

Panel D: Benchmark regression and the EM bias score controlling also for RDG-EM reversals

$\mathrm{R}_{\mathrm{i}, \mathrm{t} \mathrm{j}}=\mathrm{c}_{0, \mathrm{j}}+\mathrm{c}_{1, \mathrm{j}} \beta_{\mathrm{i}, \mathrm{t}}+\mathrm{c}_{2, \mathrm{j}} \ln (\mathrm{M})_{\mathrm{i}, \mathrm{t}}+\mathrm{c}_{3, \mathrm{j}} \ln (\mathrm{B} / \mathrm{M})_{\mathrm{i}, \mathrm{t}}+\mathrm{c}_{4, \mathrm{j}} \ln (\mathrm{A} / \mathrm{B})_{\mathrm{i}, \mathrm{t}}+\mathrm{c}_{5, \mathrm{j}}(\mathrm{E}(+) / \mathrm{M})_{\mathrm{i}, \mathrm{t}}+\mathrm{c}_{6, \mathrm{j}}(\mathrm{E} / \mathrm{M} \text { dummy })_{\mathrm{i}, \mathrm{t}}+\mathrm{c}_{7, \mathrm{j}} \ln (\mathrm{RDC} / \mathrm{M})_{\mathrm{i}, \mathrm{t}}+\mathrm{c}_{8, \mathrm{j}}(\mathrm{EM} \text { bias score })_{i, \mathrm{t}}+$ $\mathrm{c}_{9, \mathrm{j}}\left(\mathrm{EM} \text { bias score* } \mathrm{D}_{\mathrm{pn}}\right)_{\mathrm{i}, \mathrm{t}}+\mathrm{c}_{10, \mathrm{j}}\left(\mathrm{EM} \text { bias score* } \mathrm{D}_{\mathrm{np}}\right)_{\mathrm{i}, \mathrm{t}} \mathrm{e}_{\mathrm{i}, \mathrm{t}+\mathrm{j}}$

\begin{tabular}{|c|c|c|c|c|c|c|c|c|c|c|c|c|}
\hline Regressions & Intercept & Beta & Size & $\mathrm{BM}$ & AB & $\mathrm{E}(+) / \mathrm{M}$ & $\begin{array}{c}\mathrm{E} / \mathrm{M} \\
\text { Dummy }\end{array}$ & $\mathrm{RDC} / \mathrm{M}$ & $\begin{array}{c}\text { EM } \\
\text { bias } \\
\text { score }\end{array}$ & $\begin{array}{l}\text { EM bias } \\
\text { score* } D_{p n}\end{array}$ & $\begin{array}{c}\text { EM bias } \\
\text { score }{ }^{*} D_{\mathrm{np}}\end{array}$ & Adj. $\mathrm{R}^{2}$ \\
\hline \multirow{2}{*}{ Year 1} & 0.0274 & -0.0021 & -0.0006 & 0.0030 & -0.0003 & 0.0009 & -0.0017 & 0.0023 & -0.0015 & 0.0013 & -0.0025 & 0.016 \\
\hline & $(9.799)$ & $(-1.664)$ & $(-1.403)$ & $(3.252)$ & $(-0.255)$ & $(0.081)$ & $(-1.182)$ & $(4.524)$ & $(-1.128)$ & $(0.179)$ & $(-1.794)$ & \\
\hline \multirow[t]{2}{*}{ Year 2} & 0.0241 & -0.0006 & -0.0005 & 0.0006 & 0.0012 & 0.0092 & 0.0004 & 0.0019 & -0.0017 & -0.0037 & -0.0010 & 0.011 \\
\hline & $(7.366)$ & $(-0.419)$ & $(-1.260)$ & $(0.554)$ & $(0.999)$ & $(0.774)$ & $(0.220)$ & $(3.893)$ & $(-1.053)$ & $(-0.566)$ & $(-0.574)$ & \\
\hline
\end{tabular}

Panel E: Benchmark regression and the EM bias score variable for positive to negative reversals only

$\mathrm{R}_{\mathrm{i}, \mathrm{t}+\mathrm{j}}=\mathrm{c}_{0, \mathrm{j}}+\mathrm{c}_{1, \mathrm{j}} \beta_{\mathrm{i}, \mathrm{t}}+\mathrm{c}_{2, \mathrm{j}} \ln (\mathrm{M})_{\mathrm{i}, \mathrm{t}}+\mathrm{c}_{3, \mathrm{j}} \ln (\mathrm{B} / \mathrm{M})_{\mathrm{i}, \mathrm{t}}+\mathrm{c}_{4, \mathrm{j}} \ln (\mathrm{A} / \mathrm{B})_{\mathrm{i}, \mathrm{t}}+\mathrm{c}_{5, \mathrm{j}}(\mathrm{E}(+) / \mathrm{M})_{\mathrm{i}, \mathrm{t}}+\mathrm{c}_{6, \mathrm{j}}(\mathrm{E} / \mathrm{M} \text { dummy })_{\mathrm{i}, \mathrm{t}}+\mathrm{c}_{7, \mathrm{j}} \ln (\mathrm{RDC} / \mathrm{M})_{\mathrm{i}, \mathrm{t}}+\mathrm{c}_{8, \mathrm{j}}(\mathrm{EM} \text { bias score })_{\mathrm{i}, \mathrm{t}}+\mathrm{e}_{\mathrm{i}, \mathrm{t}+\mathrm{i}}$

\begin{tabular}{|c|c|c|c|c|c|c|c|c|c|c|}
\hline Year 1 & 0.0320 & -0.0010 & -0.0006 & 0.0013 & -0.0045 & -0.0171 & -0.0047 & 0.0034 & 0.0046 & 0.006 \\
\hline & $(5.385)$ & $(-0.404)$ & $(-0.921)$ & $(0.573)$ & $(-1.398)$ & $(-0.658)$ & $(-0.854)$ & $(2.925)$ & $(0.423)$ & \\
\hline Year 2 & 0.0164 & 0.0004 & 0.0001 & 0.0020 & -0.0032 & 0.0211 & 0.0087 & 0.0004 & 0.0076 & 0.002 \\
\hline & $(2.411)$ & $(0.146)$ & $(0.205)$ & $(0.795)$ & $(-0.933)$ & $(0.723)$ & $(1.392)$ & $(0.342)$ & $(0.710)$ & \\
\hline
\end{tabular}

Panel F: Benchmark regression and the EM bias score variable for negative to positive reversals only

$\mathrm{R}_{\mathrm{i}, \mathrm{t}+\mathrm{j}}=\mathrm{c}_{0, \mathrm{j}}+\mathrm{c}_{1, \mathrm{j}} \beta_{\mathrm{i}, \mathrm{t}}+\mathrm{c}_{2, \mathrm{j}} \ln (\mathrm{M})_{\mathrm{i}, \mathrm{t}}+\mathrm{c}_{3, \mathrm{j}} \ln (\mathrm{B} / \mathrm{M})_{\mathrm{i}, \mathrm{t}}+\mathrm{c}_{4, \mathrm{j}} \ln (\mathrm{A} / \mathrm{B})_{\mathrm{i}, \mathrm{t}}+\mathrm{c}_{5, \mathrm{j}}(\mathrm{E}(+) / \mathrm{M})_{\mathrm{i}, \mathrm{t}}+\mathrm{c}_{6, \mathrm{j}}(\mathrm{E} / \mathrm{M} \text { dummy })_{\mathrm{i}, \mathrm{t}}+\mathrm{c}_{7, \mathrm{j}} \ln (\mathrm{RDC} / \mathrm{M})_{\mathrm{i}, \mathrm{t}}+\mathrm{c}_{8, \mathrm{j}}(\mathrm{EM} \text { bias score })_{\mathrm{i}, \mathrm{t}}+\mathrm{e}_{\mathrm{i}, \mathrm{t}+\mathrm{j}}$

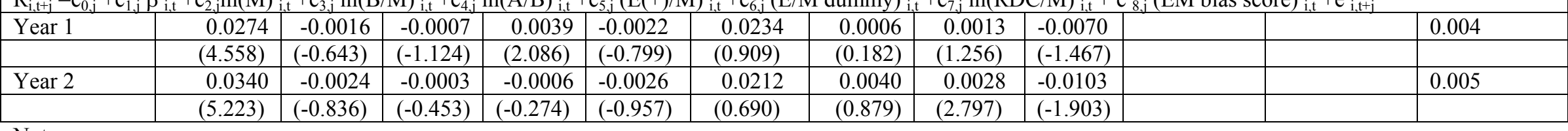

Notes:

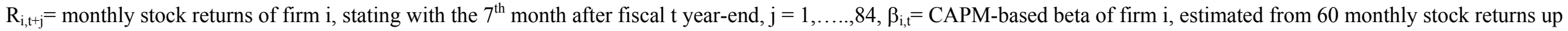

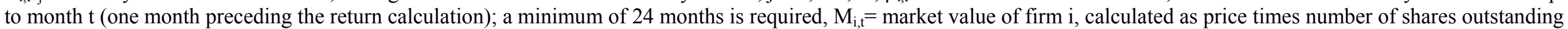

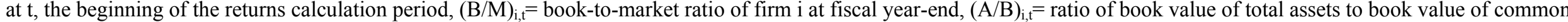

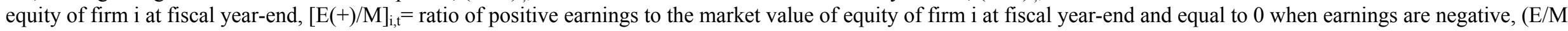

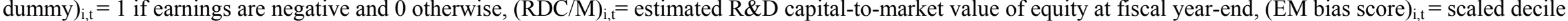

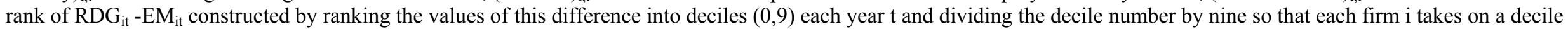

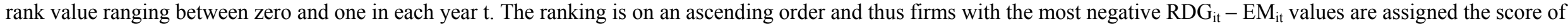

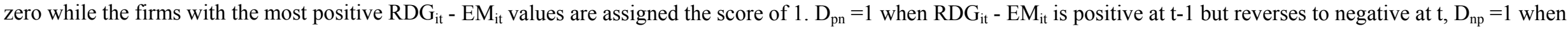
$\mathrm{RDG}_{\mathrm{it}}-\mathrm{EM}_{\mathrm{it}}$ is negative at $\mathrm{t}-1$ but reverses to positive at $\mathrm{t}$. 


\section{Table 8}

\section{Earnings Momentum Bias Reversal Analysis}

In each year from 1975 to 1995 we detect firms for which the difference R\&D growth minus earnings momentum [RDG(5)-EM(5)] reverses. For example, for year 1984 we detect firms that had RDG(5)-EM(5)>0 in 1983 but $<0$ in 1984 . This is our "positive to negative reversal" portfolio. We also detect firms that had $\mathrm{RDG}(5)-\operatorname{EM}(5)<0$ in 1983 but $>0$ in 1984 . This is our "negative to positive reversal" portfolio. The remaining firms comprise the "Non reversal" portfolio. We trace these firms five years before and one year after the reversal year. For each of these seven years and for each portfolio we report mean values of key characteristics including annual raw and abnormal returns. These returns are for the year following the disclosure of the financial statements, i.e. we start the annual return calculation from the seventh month after fiscal year end. The abnormal returns are the residuals from the regression:

$\mathrm{R}_{\mathrm{i}, \mathrm{t}+\mathrm{j}}=\mathrm{c}_{0, \mathrm{j}}+\mathrm{c}_{1, \mathrm{j}} \beta_{\mathrm{i}, \mathrm{t}}+\mathrm{c}_{2, \mathrm{j}} \ln (\mathrm{M})_{\mathrm{i}, \mathrm{t}}+\mathrm{c}_{3, \mathrm{j}} \ln (\mathrm{B} / \mathrm{M})_{\mathrm{i}, \mathrm{t}}+\mathrm{c}_{4, \mathrm{j}} \ln (\mathrm{A} / \mathrm{B})_{\mathrm{i}, \mathrm{t}}+\mathrm{c}_{5, \mathrm{j}}\left(\mathrm{E}(+)_{/ \mathrm{M}}\right)_{\mathrm{i}, \mathrm{t}}+\mathrm{c}_{6, \mathrm{j}}(\mathrm{E} / \mathrm{M} \text { dummy })_{\mathrm{i}, \mathrm{t}}+\mathrm{c}_{7, \mathrm{j}} \ln (\mathrm{RDC} / \mathrm{M})_{\mathrm{i}, \mathrm{t}}+\mathrm{e}_{\mathrm{i}, \mathrm{t}+\mathrm{j}}$ We run this regression each year for all firms and we report the mean residuals for the firms that belong to each portfolio.

\section{Panel A: "positive to negative reversal" portfolio}

\begin{tabular}{|c|c|c|c|c|c|c|c|}
\hline & & & selative & reversal & & & \\
\hline & $t-5$ & $t-4$ & $t-3$ & $t-2$ & $t-1$ & t & $t+1$ \\
\hline R\&D growth - EM & -0.448 & 1.326 & 1.157 & 0.586 & 3.084 & -7.028 & -3.048 \\
\hline Raw returns & 0.182 & 0.200 & 0.247 & 0.244 & 0.232 & 0.180 & 0.159 \\
\hline Abnormal returns & -0.019 & 0.013 & 0.027 & 0.082 & 0.070 & 0.006 & 0.001 \\
\hline R\&D growth rate & 0.996 & 1.450 & 0.963 & 0.894 & 0.719 & 0.454 & 0.655 \\
\hline Earnings momentum (EM) & 1.443 & 0.124 & -0.194 & 0.308 & -2.365 & 7.482 & 3.703 \\
\hline R\&D-Capitalized EM & 0.289 & -0.311 & 0.399 & -1.071 & -1.220 & 2.314 & 0.054 \\
\hline R\&D-to-sales & 0.061 & 0.067 & 0.147 & 0.087 & 0.103 & 0.109 & 0.125 \\
\hline Earnings-to-price & 0.074 & 0.062 & 0.060 & 0.057 & 0.049 & 0.069 & 0.062 \\
\hline Book-to-price & 0.853 & 0.857 & 0.837 & 0.790 & 0.746 & 0.697 & 0.678 \\
\hline Beta & 1.190 & 1.188 & 1.177 & 1.157 & 1.151 & 1.141 & 1.124 \\
\hline Market capitalization & 1128 & 1193 & 1200 & 1307 & 1368 & 1539 & 1863 \\
\hline No. of firms & 90 & 98 & 107 & 119 & 132 & 132 & 123 \\
\hline
\end{tabular}


Table 8: continued

Panel B: "negative to positive reversal" portfolio

\begin{tabular}{lccccccc} 
& \multicolumn{3}{c}{ Years relative to the reversal year t } & & $t$ & $t+1$ \\
& $t-5$ & $t-4$ & $t-3$ & $t-2$ & $t-1$ & 0.527 & 0.421 \\
R\&D growth - EM & 0.956 & -0.507 & -0.256 & -1.601 & -5.817 & 0.176 \\
Raw returns & 0.304 & 0.246 & 0.267 & 0.151 & 0.110 & 0.168 & 0.176 \\
Abnormal returns & 0.090 & 0.048 & 0.050 & 0.003 & -0.036 & -0.008 & 0.012 \\
R\&D growth rate & 0.882 & 0.903 & 0.699 & 0.652 & 0.622 & 0.941 & 0.855 \\
Earnings momentum & -0.074 & 1.411 & 0.954 & 2.252 & 6.439 & -3.586 & 0.434 \\
R\&D-Capitalized EM & 0.554 & 0.545 & 0.037 & 0.173 & 2.481 & -0.845 & 0.762 \\
R\&D-to-sales & 0.060 & 0.069 & 0.057 & 0.055 & 0.096 & 0.140 & 0.855 \\
Earnings-to-price & 0.071 & 0.066 & 0.069 & 0.064 & 0.072 & 0.052 & 0.052 \\
Book-to-market & 0.923 & 0.856 & 0.799 & 0.738 & 0.677 & 0.724 & 0.719 \\
Beta & 1.207 & 1.202 & 1.184 & 1.177 & 1.153 & 1.138 & 1.109 \\
Market capitalization & 1066 & 1117 & 1237 & 1258 & 1179 & 1262 & 1488 \\
No. of firms & 81 & 89 & 97 & 105 & 118 & 118 & 107
\end{tabular}


Table 8: continued

Panel C: "Non reversal" portfolio

\begin{tabular}{|c|c|c|c|c|c|c|c|}
\hline & & & relative & reversal & & & \\
\hline & $t-5$ & $t-4$ & $t-3$ & $t-2$ & $t-1$ & t & $t+1$ \\
\hline R\&D growth - EM & 0.292 & -0.063 & 0.406 & 0.552 & 0.787 & 1.328 & 0.237 \\
\hline Raw returns & 0.174 & 0.158 & 0.187 & 0.128 & 0.150 & 0.178 & 0.165 \\
\hline Abnormal returns & -0.011 & -0.012 & -0.013 & -0.019 & -0.007 & -0.001 & -0.002 \\
\hline R\&D growth rate & 1.231 & 1.134 & 1.150 & 1.084 & 1.080 & 0.838 & 0.734 \\
\hline Earnings momentum & 0.939 & 1.196 & 0.744 & 0.533 & 0.293 & -0.491 & 0.497 \\
\hline R\&D-Capitalized EM & 0.670 & 0.167 & -0.114 & 0.272 & -0.165 & -0.278 & -0.446 \\
\hline R\&D-to-sales & 0.048 & 0.054 & 0.066 & 0.146 & 0.245 & 0.334 & 0.477 \\
\hline Earnings-to-price & 0.079 & 0.073 & 0.066 & 0.059 & 0.053 & 0.053 & 0.052 \\
\hline Book-to-price & 0.759 & 0.764 & 0.766 & 0.759 & 0.738 & 0.745 & 0.719 \\
\hline Beta & 1.207 & 1.189 & 1.181 & 1.166 & 1.153 & 1.141 & 1.120 \\
\hline Market capitalization & 1378 & 1408 & 1438 & 1469 & 1458 & 1623 & 1941 \\
\hline No. of firms & 401 & 437 & 476 & 523 & 578 & 579 & 536 \\
\hline
\end{tabular}


Table 9

Simultaneous ROE and Earnings Momentum Bias Reversal Analysis

In each year from 1975 to 1995 we detect firms for which both differences RDG/[(RDG/2)+1]\}-ROE and RDG(5)-EM(5) reverse. For example, for year 1980 we detect firms that had RDG/[(RDG/2)+1]\}-ROE and RDG(5)-EM(5) $>0$ in 1979 but $<0$ in 1980 . This is our "positive to negative reversal" portfolio. We also detect firms that had RDG/[(RDG/2)+1]\}-ROE and RDG(5)-EM(5) $<0$ in 1979 but $>0$ in 1980 . This is our "negative to positive reversal" portfolio. We trace these firms five years before and one year after the reversal year. For each of these seven years and for each portfolio we report mean values of key characteristics including annual raw and abnormal returns. These returns are for the year following the disclosure of the financial statements, i.e. we start the annual return calculation from the seventh month after fiscal year end. The abnormal returns are the residuals from the regression:

$\mathrm{R}_{\mathrm{i}, \mathrm{t}+\mathrm{j}}=\mathrm{c}_{0, \mathrm{j}}+\mathrm{c}_{1, \mathrm{j}} \beta_{\mathrm{i}, \mathrm{t}}+\mathrm{c}_{2, \mathrm{j}} \ln (\mathrm{M})_{\mathrm{i}, \mathrm{t}}+\mathrm{c}_{3, \mathrm{j}} \ln (\mathrm{B} / \mathrm{M})_{\mathrm{i}, \mathrm{t}}+\mathrm{c}_{4, \mathrm{j}} \ln (\mathrm{A} / \mathrm{B})_{\mathrm{i}, \mathrm{t}}+\mathrm{c}_{5, \mathrm{j}}(\mathrm{E}(+) / \mathrm{M})_{\mathrm{i}, \mathrm{t}}+\mathrm{c}_{6, \mathrm{j}}(\mathrm{E} / \mathrm{M} \text { dummy })_{\mathrm{i}, \mathrm{t}}+\mathrm{c}_{7, \mathrm{j}} \ln (\mathrm{RDC} / \mathrm{M})_{\mathrm{i}, \mathrm{t}}+\mathrm{e}_{\mathrm{i}, \mathrm{t}+\mathrm{j} .}$ We run this regression each year for all firms and we report the mean residuals for the firms that belong to each portfolio.

\section{Panel A: "positive to negative reversal" portfolio}

\begin{tabular}{|c|c|c|c|c|c|c|c|}
\hline & & & $\mathrm{s}$ relative & eversal & & & \\
\hline & $t-5$ & $t-4$ & $t-3$ & $t-2$ & $t-1$ & t & $t+1$ \\
\hline Raw returns & 0.135 & 0.120 & 0.177 & 0.313 & 0.337 & 0.195 & 0.164 \\
\hline Abnormal returns & -0.076 & -0.093 & -0.049 & 0.102 & 0.130 & 0.007 & -0.028 \\
\hline Earnings-to-price & 0.104 & 0.085 & 0.072 & 0.069 & 0.052 & 0.090 & 0.075 \\
\hline Market capitalization & 866 & 925 & 907 & 984 & 1180 & 1292 & 1492 \\
\hline No. of firms & 28 & 30 & 31 & 31 & 31 & 31 & 29 \\
\hline
\end{tabular}

Panel B: "negative to positive reversal" portfolio

\begin{tabular}{|c|c|c|c|c|c|c|c|}
\hline Raw returns & 0.320 & 0.255 & 0.327 & 0.166 & 0.098 & 0.141 & 0.214 \\
\hline Abnormal returns & 0.109 & 0.033 & 0.125 & -0.010 & -0.071 & -0.026 & 0.024 \\
\hline Earnings-to-price & 0.088 & 0.088 & 0.091 & 0.087 & 0.099 & 0.051 & 0.060 \\
\hline Market capitalization & 722 & 764 & 875 & 965 & 938 & 1039 & 1206 \\
\hline No. of firms & 29 & 31 & 31 & 31 & 31 & 31 & 28 \\
\hline
\end{tabular}




\section{Figure 1}

\section{ROE Bias Reversal Analysis}

Annual Abnormal Returns (AR) are plotted for three portfolios formed based on ROE bias reversals. In each year from 1975 to 1995 we detect firms for which the difference $\mathrm{RDG} /[(\mathrm{RDG} / 2)+1]\}-\mathrm{ROE}$ reverses. For example, for year 1980 we detect firms that had $\mathrm{RDG} /[(\mathrm{RDG} / 2)+1]\}-\mathrm{ROE}>0$ in 1979 but $<0$ in 1980. This is our "positive to negative reversal" (PN) portfolio. We also detect firms that had RDG/[(RDG/2)+1]\}-ROE $<0$ in 1979 but $>0$ in 1980. This is our "negative to positive reversal" (NP) portfolio. The remaining firms comprise the "Non reversal" (NR) portfolio. We trace these firms five years before and one year after the reversal year. For each of these seven years and for each portfolio we calculate annual abnormal returns using the residuals of the following regression: $\mathrm{R}_{\mathrm{i}, \mathrm{t}+\mathrm{j}}=\mathrm{c}_{0, \mathrm{j}}+\mathrm{c}_{1, \mathrm{j}} \beta_{\mathrm{i}, \mathrm{t}}+\mathrm{c}_{2, \mathrm{j}} \ln (\mathrm{M})_{\mathrm{i}, \mathrm{t}}+\mathrm{c}_{3, \mathrm{j}} \ln (\mathrm{B} / \mathrm{M})_{\mathrm{i}, \mathrm{t}}+\mathrm{c}_{4, \mathrm{j}} \ln (\mathrm{A} / \mathrm{B})_{\mathrm{i}, \mathrm{t}}+$ $\mathrm{c}_{5, \mathrm{j}}(\mathrm{E}(+) / \mathrm{M})_{\mathrm{i}, \mathrm{t}}+\mathrm{c}_{6, \mathrm{j}}(\mathrm{E} / \mathrm{M} \text { dummy })_{\mathrm{i}, \mathrm{t}}+\mathrm{c}_{7, \mathrm{j}} \ln (\mathrm{RDC} / \mathrm{M})_{\mathrm{i}, \mathrm{t}}+\mathrm{e}_{\mathrm{i}, \mathrm{t}+\mathrm{j}}$.

These returns are for the year following the disclosure of the financial statements, i.e. we start the annual return calculation from the seventh month after fiscal year end.

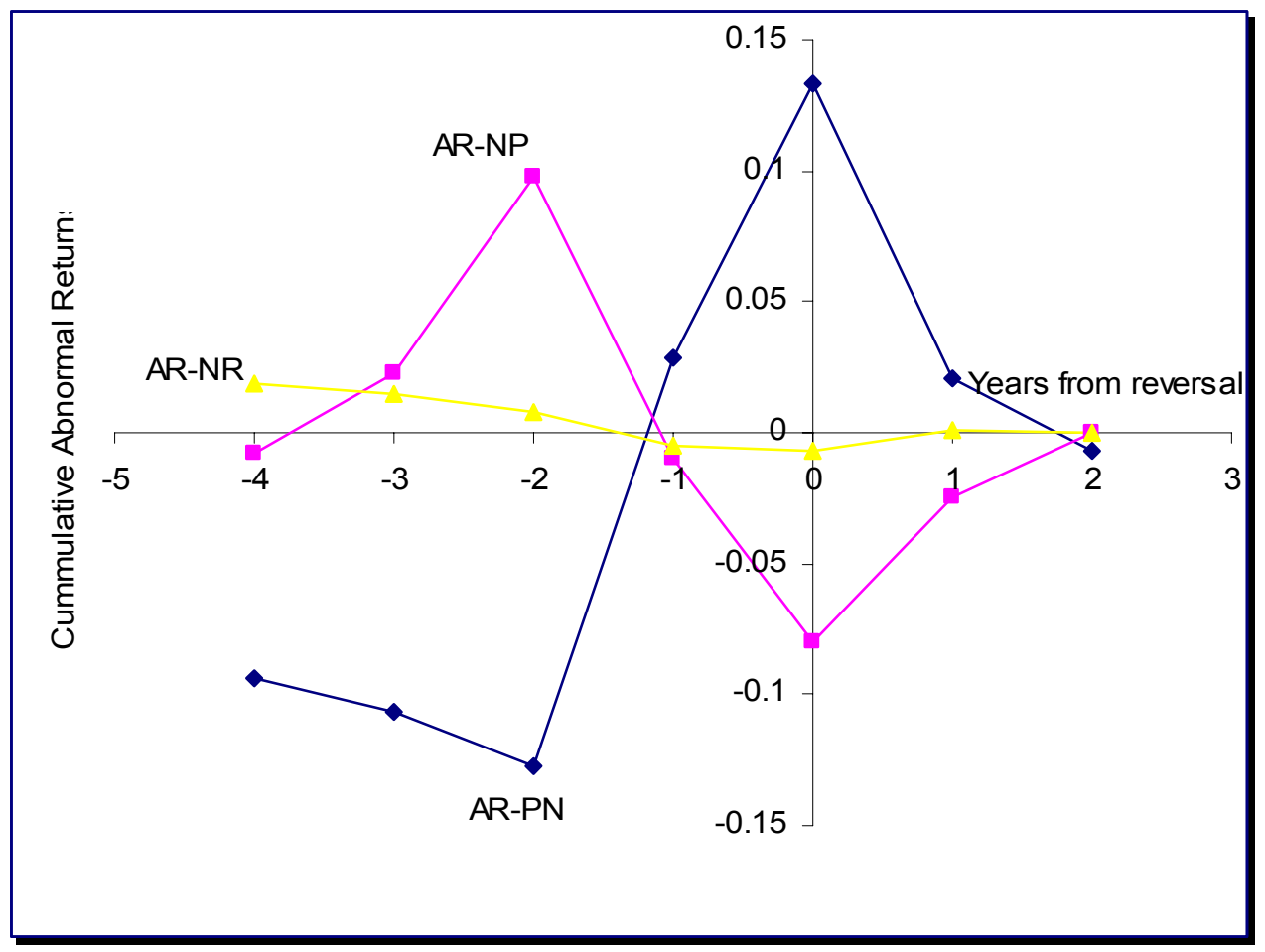


Figure 2

\section{Earnings Momentum Bias Reversal Analysis}

Annual Abnormal Returns (AR) are plotted for three portfolios formed based on ROE bias reversals. In each year from 1975 to 1995 we detect firms for which the difference R\&D growth minus earnings momentum [RDG(5)-EM(5)] reverses. For example, for year 1980 we detect firms that had RDG(5)-EM(5) $>0$ in 1979 but $<0$ in 1980. This is our "positive to negative reversal" (PN) portfolio. We also detect firms that had RDG(5)$\operatorname{EM}(5)<0$ in 1979 but $>0$ in 1980. This is our "negative to positive reversal" (NP) portfolio. The remaining firms comprise the "Non reversal" (NR) portfolio. We trace these firms five years before and one year after the reversal year. For each of these seven years and for each portfolio we calculate annual abnormal returns using the residuals of the following regression: $\mathrm{R}_{\mathrm{i}, \mathrm{t}+\mathrm{j}}=\mathrm{c}_{0, \mathrm{j}}+\mathrm{c}_{1, \mathrm{j}} \beta_{\mathrm{i}, \mathrm{t}}+\mathrm{c}_{2, \mathrm{j}} \ln (\mathrm{M})_{\mathrm{i}, \mathrm{t}}+\mathrm{c}_{3, \mathrm{j}} \ln (\mathrm{B} / \mathrm{M})_{\mathrm{i}, \mathrm{t}}+$ $\mathrm{c}_{4, \mathrm{j}} \ln (\mathrm{A} / \mathrm{B})_{\mathrm{i}, \mathrm{t}}+\mathrm{c}_{5, \mathrm{j}}(\mathrm{E}(+) / \mathrm{M})_{\mathrm{i}, \mathrm{t}}+\mathrm{c}_{6, \mathrm{j}}\left(\mathrm{E} / \mathrm{M}\right.$ dummy $_{\mathrm{i}, \mathrm{t}}+\mathrm{c}_{7, \mathrm{j}} \ln (\mathrm{RDC} / \mathrm{M})_{\mathrm{i}, \mathrm{t}}+\mathrm{e}_{\mathrm{i}, \mathrm{t}+\mathrm{j}}$.

These returns are for the year following the disclosure of the financial statements, i.e. we start the annual return calculation from the seventh month after fiscal year end.

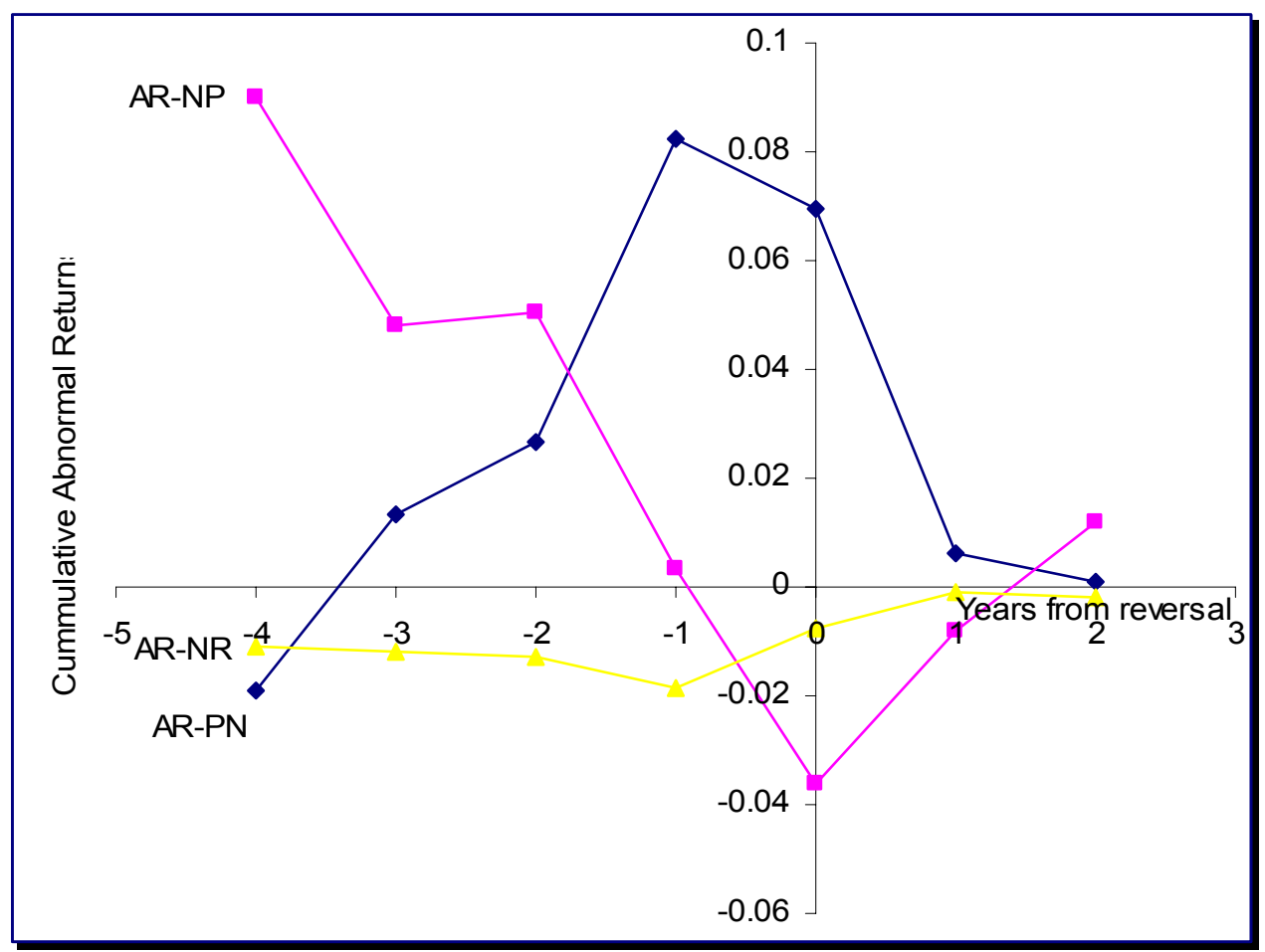


Figure 3

Simultaneous ROE and Earnings Momentum Bias Reversal Analysis

Annual Abnormal Returns (AR) are plotted for two portfolios formed based on both ROE bias and earnings momentum bias reversals. In each year from 1975 to 1995 we detect firms for which both differences $\mathrm{RDG} /[(\mathrm{RDG} / 2)+1]\}-\mathrm{ROE}$ and $\mathrm{RDG}(5)-\mathrm{EM}(5)$ reverse. For example, for year 1980 we detect firms that had RDG/[(RDG/2)+1]\}-ROE and $\mathrm{RDG}(5)-\mathrm{EM}(5)>0$ in 1979 but $<0$ in 1980. This is our "positive to negative reversal" (PN) portfolio. We also detect firms that had RDG/[(RDG/2)+1]\}-ROE and RDG(5)-EM(5) $<0$ in 1979 but $>0$ in 1980. This is our "negative to positive reversal" (NP) portfolio. We trace these firms five years before and one year after the reversal year. For each of these seven years and for each portfolio we calculate annual abnormal returns using the residuals of the following regression:

$\mathrm{R}_{\mathrm{i}, \mathrm{t}+\mathrm{j}}=\mathrm{c}_{0, \mathrm{j}}+\mathrm{c}_{1, \mathrm{j}} \beta_{\mathrm{i}, \mathrm{t}}+\mathrm{c}_{2, \mathrm{j}} \ln (\mathrm{M})_{\mathrm{i}, \mathrm{t}}+\mathrm{c}_{3, \mathrm{j}} \ln (\mathrm{B} / \mathrm{M})_{\mathrm{i}, \mathrm{t}}+\mathrm{c}_{4, \mathrm{j}} \ln (\mathrm{A} / \mathrm{B})_{\mathrm{i}, \mathrm{t}}+\mathrm{c}_{5, \mathrm{j}}(\mathrm{E}(+) / \mathrm{M})_{\mathrm{i}, \mathrm{t}}+$ $\mathrm{c}_{6, \mathrm{j}}(\mathrm{E} / \mathrm{M} \text { dummy })_{\mathrm{i}, \mathrm{t}}+\mathrm{c}_{7, \mathrm{j}} \ln (\mathrm{RDC} / \mathrm{M})_{\mathrm{i}, \mathrm{t}}+\mathrm{e}_{\mathrm{i}, \mathrm{t}+\mathrm{j}}$.

These returns are for the year following the disclosure of the financial statements, i.e. we start the annual return calculation from the seventh month after fiscal year end.

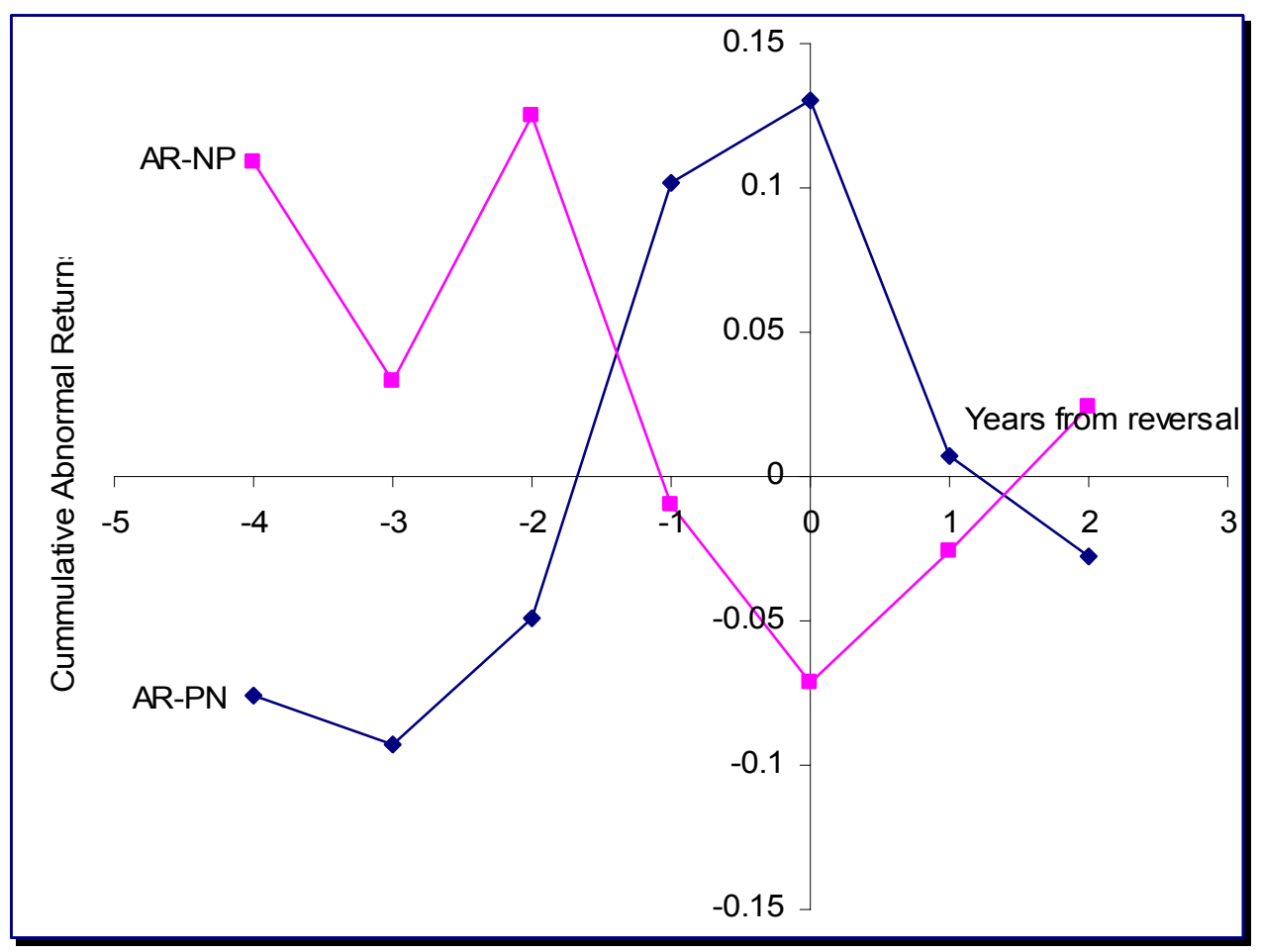

